\title{
Biology of the freshwater diatom Didymosphenia: a review
}

\author{
B. A. Whitton · N. T. W. Ellwood · B. Kawecka
}

Received: 20 December 2008/Revised: 24 February 2009/ Accepted: 12 March 2009/Published online: 14 May 2009

(C) Springer Science+Business Media B.V. 2009

\begin{abstract}
Features of the colonial diatom Didymosphenia are reviewed, especially $D$. geminata. Although there is a long record of its occurrence in north temperate regions, mass growths have been reported much more widely in recent years. Contrary to some statements in the literature, there are also reliable older records for the southern hemisphere, though the first report of mass growth was in New Zealand in 2004. The annual cycle of morphological changes in D. geminata in northern England, and probably elsewhere, includes a winter period when motile cells are attached to the substratum followed by spring when stalks start to develop. These raise cells into the water column and provide a site for phosphatase activity. Environmental factors associated with success include absence of extreme floods, high light, $\mathrm{pH}$ above neutral and nutrient chemistry.
\end{abstract}

Handling editor: Pierluigi Viaroli

B. A. Whitton $(\varangle) \cdot$ N. T. W. Ellwood

School of Biological and Biomedical Sciences, University

of Durham, Durham DH1 3LE, UK

e-mail: b.a.whitton@durham.ac.uk

N. T. W. Ellwood

Dipartimento di Scienze Geologiche, Università Roma

Tre, Largo San Leonardo Murialdo 1, 00146 Rome, Italy

B. Kawecka

Institute of Nature Conservation, Polish Academy of Sciences, A. Mickiewicz Avenue 33, 31-120 Kraków, Poland
D. geminata often, but not always, occurs in waters where the $\mathrm{N}: \mathrm{P}$ ratio is high for much of the year, but the key factor is the ratio of organic to inorganic phosphate. D. geminata thrives where organic $\mathrm{P}$ is predominant and the overall $\mathrm{P}$ concentration is low enough for organic $\mathrm{P}$ to be an important $\mathrm{P}$ source. It is unknown whether organic $\mathrm{N}$ can be used. Environmental changes increasing the relative importance of organic $\mathrm{P}$ are likely to favour D. geminata. Likely examples are increased N:P due to atmospheric $\mathrm{N}$ deposition and changes in form and seasonality of $\mathrm{P}$ release from organic-rich soils due to climatic warming. The nutrient chemistry of deep water released from dams to rivers also needs investigation. To what extent are genetic changes occurring in response to environmental changes and are new ecotypes spreading round the world? In spite of many adverse reports about $D$. geminata, such as detached mats blocking water pipes, there is still doubt about the extent to which it causes problems, particularly for fish. There have been few adverse effects on migratory salmonids in Europe and North America, but at least one report of harm to a brown trout population in USA. In New Zealand, it has caused serious problems for water sports, although it remains open to question how much adverse effect it has had on fish populations. If the presence of microcystins in or associated with D. geminata, as indicated recently for two populations, proves to be widespread and at sufficiently high concentration, their possible accumulation in fish requires study. Where control is required, this could 
be achieved by enhancing the ratio of inorganic to organic phosphate in the water early in the growth season. Practical ways to achieve this are suggested.

Keywords Didymosphenia - Worldwide status · Sampling · Stalk · Nutrients · Organic phosphate · Catchment · Environmental change ·

Nuisance problems $\cdot$ Control

$\begin{array}{ll}\text { Abbreviations } \\ \text { BCIP-NBT } & \begin{array}{l}\text { 5-bromo-4-chloro-3-indolyl phosphate- } \\ \text { nitroblue tetrazolium }\end{array} \\ \text { FOP } & \text { Filtrable organic phosphorus } \\ \text { FRP } & \text { Filtrable reactive phosphorus } \\ \text { TIN } & \text { Total inorganic nitrogen } \\ \text { TFP } & \text { Total filtrable phosphorus } \\ \text { TP } & \text { Total phosphorus }\end{array}$

\section{Introduction}

The increasing frequency of reports of mass growths of the colonial diatom Didymosphenia at sites with no previous record has led to it becoming notorious in some countries. In New Zealand in particular, its discovery in 2004 and the suggestion that it was a recent invader to the country (Biggs et al., 2006) led to a great deal of publicity. An indication of the huge increase in interest in Didymosphenia is shown by entries on Google, which rose from a few hundred in early 2004 to about 13,000 in 2008. Most accounts mention D. geminata, but about nine other living species have been described, based on moderate differences in frustule morphology. D. geminata occurs in both running and standing waters (CanterLund \& Lund, 1995). The present review aims to assess the status of Didymosphenia worldwide and to understand the factors favouring its growth, including its recent increase. This should in turn help to predict where large growths are likely to develop and to suggest methods for minimizing them where they are considered a nuisance.

\section{Sources of information}

Although there are many records in the older literature (see Kawecka \& Sanecki, 2003), much recent information is in conference abstracts, reports or placed on the internet. We have checked much of the material on Didymosphenia accessible using the internet from January 2007 to December 2008. However, this varies in its reliability; it is sometimes confusing or even contradictory and information about early records is frequently misquoted.

Several problems influence the interpretation of past results. Many microscopy studies used cleaned frustules, and so lack information about the proportions of live and dead cells or features of live cells such as the stalks, which are a prominent feature of Didymosphenia colonies. Reports on environmental factors favouring Didymosphenia are based largely on correlations between occurrence and a particular factor and it is open to question what influence that factor really has. Field studies in several countries have made the authors increasingly aware of the importance of spatial distribution within a whole river system, temporal changes in biology during the year and sometimes marked changes from year to year. Where we have included previously unpublished data, we have tried to ensure the information is unambiguous. The account includes hypotheses and queries, because much could be answered by straightforward observation and simple experiments.

\section{Taxonomy and morphology}

Didymosphenia geminata (Lyngbye) M. Schmidt 1899 (Fig. 1) was first described from the Faroes (Lyngbye, 1819) as Echinella geminata, soon renamed Gomphonema geminatum (Lyngbye) Agardh 1824. However, Dawson (1973a) considered that Müller (1786) provided an even earlier record. Dawson summarized the earlier nomenclatural history of Didymosph(a)enia, including an explanation as to why she rejected the suggestion by Carter (1960) to recombine the genus with Gomphonema. Many older records are still only accessible on the internet as G. geminatum (or G. geminata). Based largely on frustule structure, Kociolek \& Stoermer (1988) considered that Didymosphenia is more related to Cymbella and Encyonema than to Gomphonema and Gomphoneis. Ultrastructural features of Didymosphenia geminata support this, including the relative positions of the nucleus, pyrenoid and chromatophore, as well as the appearance of the 
Fig. 1 Examples of the morphological range shown by Didymosphenia SEM micrographs of frustules: (A, B) D. geminata from R. Sljudjanka, Russia; (C) D. clavaherculis from $\mathrm{R}$. Sljudjanka; (D, E) D. geminata from High Tatra Mts, Poland. Scale bar applies to all frustules
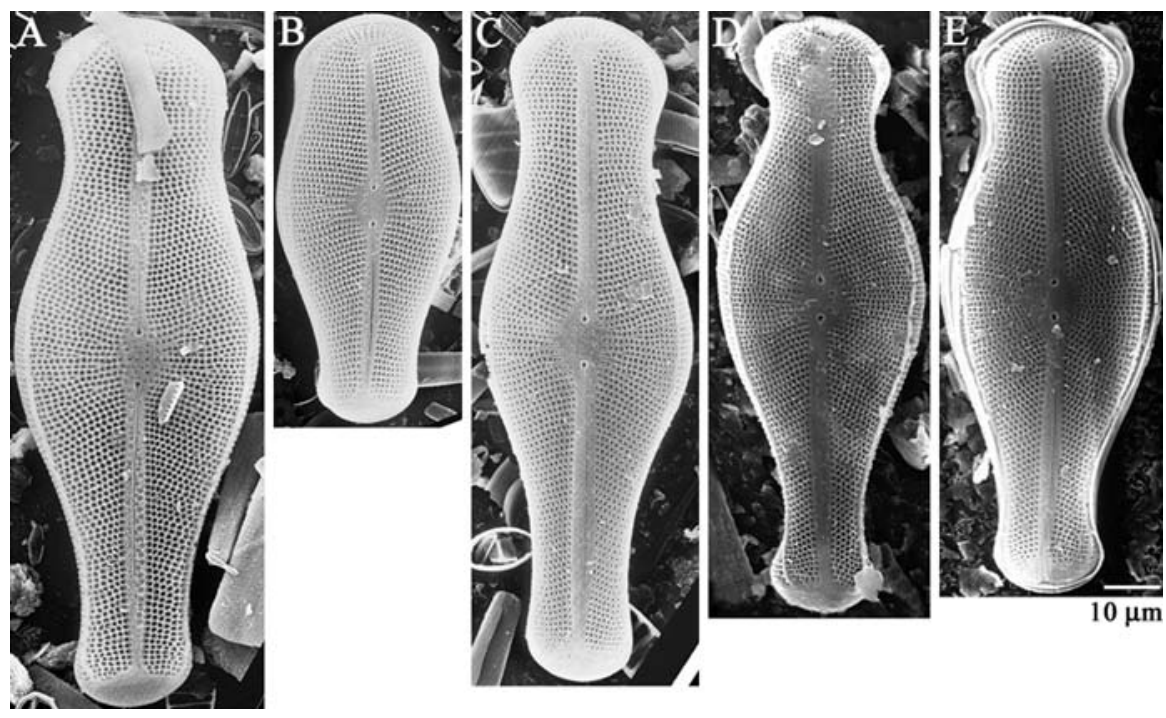

Table 1 Taxa which have been recognized in Didymosphenia

D. clavaherculis (Ehrenberg) Metzeltin \& Lange-Bertalot (1995)

D. curvata (Skvortzow \& D. I. Meyer 1928) Metzeltin \& Lange-Bertalot (1995)

D. curvirostrum (Tempère \& Brun) M. Schmidt

D. dentata Dorogostaiský 1904

D. geminata (Lyngbye) M. Schmidt + morphotypes geminata, capitata, subcapitata

D. lineata Skabichevsky (1983)

D. neocaledonica Manguin (1962)

D. pumila Metzeltin \& Lange-Bertalot (1995)

D. siberica (Grunow) M. Schmidt $=D$. geminata var. sibirica Grunow; includes f. anomala

D. tatrensis Mrozińska et al. (2006a)

D. fossilis Horikawa \& Okuno (1944) in Okuno (1944): see Tuji (2004)

Metzeltin and Lange-Bertalot (1995) and Mrozińska et al. (2006a) provide more detailed guides to the literature on living species, and Tuji (2004) to the fossil D. fossilis; the latter differs considerably from others. The spellings siberica and sibirica are given in the text according to how they are quoted by a particular author, but we follow Mrozińska et al. in using siberica for general comments

diatotepum (Moffat, 1994). About 11 species have been recognized (Table 1), though only five were treated as species by Metzeltin \& Lange-Bertalot (1995): clavaherculis, curvata, geminata, siberica and pumila. Mrozińska et al. (2006a) not only comment on the others, but describe a new one, $D$. tatrensis, which is clearly distinct, in spite of coming from a region well studied by phycologists. Overall, however, there is a lack of agreement on the taxonomic limits of species, which hinders interpretation of evolution and past and present distribution.

Dawson's (1973a) study provided a detailed account of frustule structure based on samples from a fast-flowing river on the Isle of Mull, Scotland, and the submerged part of a wooden landing stage in Lake Baikal. She identified both as D. geminata, though the latter was considered to conform to var. stricta M. Schmidt, because the apices were less inflated. Subsequently, further differences were recognized (apparently based on the one L. Baikal sample) and the L. Baikal organism was treated as the species, D. sibirica (Grun.) M. Schmidt (Dawson, 1973b). Populations of D. geminata in different rivers can appear distinct (e.g. Bhatt et al., 2008), but there can also be considerable diversity within one small region or even one catchment (Antoine \& BensonEvans, 1983; Kawecka, in press b). Some of the variation in frustule structure in populations at an upstream site on the R. Wye, Wales, was attributed by Antoine and Benson-Evans as teratological forms. The characters listed were "valves with bifurcated or eccentric valves, irregular lesion-like patches of striations, completely distorted arrangement of striations, abnormal arrangement of striations at the apex or base, raphes not extended to the base and lower raphe segmented'. However, Antoine and BensonEvans also suggested that the finding of some (special) forms more than once could indicate genetic 
variation. Material from other sites in Wales, Scotland and England showed a wider range of variation than previously reported with respect to length, maximum width and number and arrangement of the central pores. These results were discussed further by Antoine \& Benson-Evans (1986) and compared with other teratological observations on diatoms by Falasco et al. (2009).

Among the morphological features described for D. geminata is a series of rows of minute, simple, round pores at the basal pole of the frustule, now usually termed apical pore field (Kociolek \& Stoermer, 1988). These were suggested to secrete mucilage (Dawson, 1973a) or mucilage stalks (Round et al., 1990). It seems probable that the main role of these pores is associated with stalk formation, though presumably also mucilage, if there is a narrow layer surrounding the main part of the stalk (see below).

The stalks of a $D$. geminata population from $\mathrm{R}$. Coquet, N-E England, in early summer had a striated appearance and this became more obvious in old stalks (unpublished data). There was little, if any, trend for the stalk to be wider at the base of a colony. In view of the morphological importance of the stalk, it is strange that stalks are ignored in taxonomic studies, especially when they may prove one of the most variable features within the genus; for instance, do smaller-celled forms of $D$. geminata have smaller stalks? The stalks of $D$. geminata and D. tatrensis in the R. Białka, Poland, showed marked differences at the uppermost site where both species were found in June 2008 (unpublished data). The mean values for stalk width were 20 and $13.2 \mu \mathrm{m}$, respectively, a larger difference than might be expected from the slightly smaller cell size of $D$. tatrensis. The crosssectional area of the stalk is 2.2 times less in $D$. tatrensis, and therefore, presumably requires considerably less fixed carbon for a particular length of stalk, in addition to having an increased surface area for passage of organic phosphate. As D. geminata is far more successful world-wide, perhaps the wider stalk has superior mechanical properties. It would be worth investigating whether the narrower-stalked species is associated with situations with less light and hence less available fixed carbon.

A more detailed assessment of the status of the various taxa lies outside the scope of this review and, in any case, is best left until molecular studies have been made. However, caution should be used in assuming all records of $D$. geminata made in routine surveys are in fact this species.

\section{Growth and seasonal changes in morphology}

In nature, D. geminata can be found attached to substrata as individual cells without stalks, or stalked cells in approximately hemispherical colonies or forming an extensive mat. Thick mats often reach $3 \mathrm{~cm}$ or more in depth, though Spaulding \& Elwell (2007) report values $>20 \mathrm{~cm}$. It is difficult to consider how a branching pattern originating from stalks attached to the substratum could achieve this thickness; therefore, observations are needed on deep mats. The source of the cells forming colonies at a particular site is usually unclear-whether they are produced in situ or depend largely or in part on upstream populations? Unless other literature is mentioned, the following is based on the UK and sites in other geographical regions may show different annual cycles.

Our observations have mostly been made on streams and rivers in northern England where there are abundant growths in summer; two of the sites (Stony Gill and R. Coquet) are those described by Ellwood \& Whitton (2007). In late winter, algal films on rocks sometimes include $D$. geminata cells and these often show motility when viewed under the microscope, reaching speeds of $10 \mu \mathrm{m} \mathrm{s}^{-1}$ in the laboratory (Whitton \& Ellwood, 2008). Some time in early spring, scattered colonies appear on rocks and these increase in size and become more frequent during late spring and summer. At this time, it is hard to find motile cells under the microscope and any movement is slow. Occasionally, colonies disappear altogether in late summer, but often many persist, mostly as stalks without cells. When a stream has masses of persistent stalks with few cells, it can appear to the public as if covered with sheep wool, as first noted by Hassall (1845). The Brusago stream in the Province of Trento, Italy, differs from this seasonal cycle in that the mats persist through the winter, being present in February even under ice layers (Beltrami et al., 2008c). Several other accounts (see Table 2) mention mats in winter, but it is unclear whether new stalks develop at this time.

Another unknown is whether an individual colony develops from one cell or by aggregation of a number 


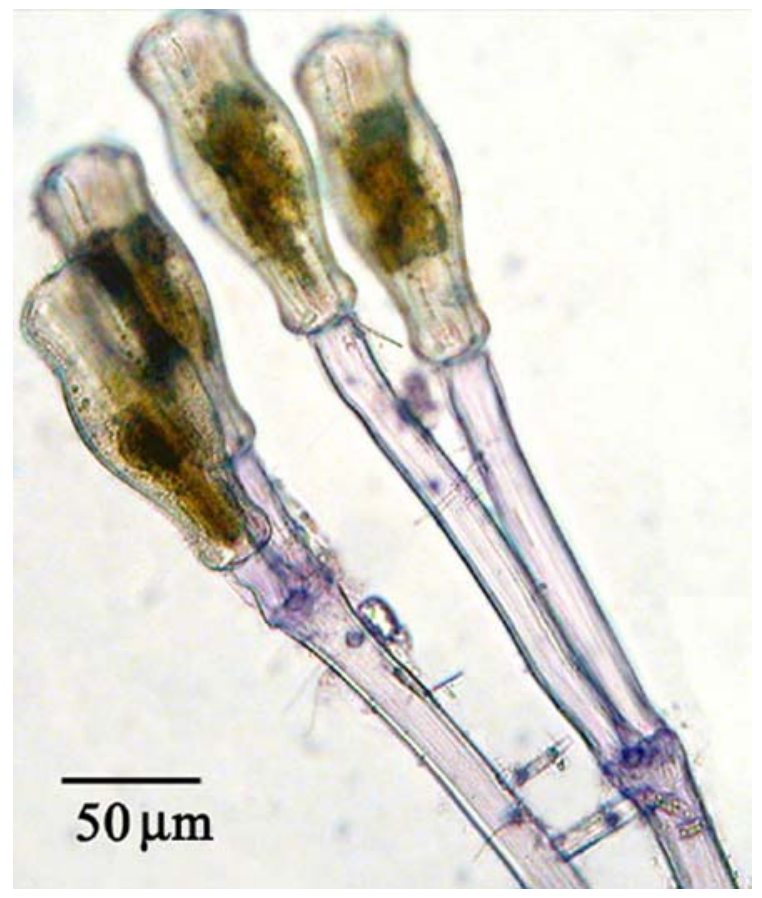

Fig. 2 Stalks of D. geminata from R. Coquet, UK. (Stalks have been stained lightly for phosphomonoesterase activity to enhance contrast.)

of motile cells. However, colonies of the cyanobacterium Rivularia, which sometimes occur slightly further upstream of sites with Didymosphenia geminata (Whitton \& Crisp, 1984), do form by aggregation of motile hormogonia (Whitton, 2002). In the case of Rivularia, molecular studies have shown that this can lead to genetic variation within a single colony (Berrendero et al., 2008). If aggregation is the norm in Didymosphenia, this would require a sufficiently high inoculum density. Whether or not aggregation is involved, each cell loses its motility, becomes attached to the substratum by an adhesive pad (Gretz et al., 2006) and develops a stalk.

The stalks divide each time the cell divides and a mature colony includes at least three branchings, sometimes more. In some colonies, all the stalks are similar in length, whereas in others, there are considerable differences, particularly between the two stalks of the final bifurcation, where one stalk may be much shorter than the other (Fig. 2). Cholnoky (1924) showed similar asymmetric branching in Gomphonema stalks starting with the second division. The overall result is a branched structure with stalks intercalating and coalescing to form an aggregate 'woven fabric' that contains algae, macroinvertebrates, detritus and other stream debris (Gretz, 2008).

One of the most important questions to be resolved is the extent to which mucilage has a role for Didymosphenia geminata. The base of the stalk forms a small pad and there is sometimes a little mucilage around this, but otherwise, the authors have never seen visually obvious mucilage in the colony, something already noted by Hassall (1845): 'It is not in the least mucous, but is of a spongy texture'. However, motile cells probably form some mucilage similar to that described for motile cells of Achnanthes longipes and Cymbella cistula (Wang et al., 2000) and there is perhaps also sometimes a similar narrow layer around the stalks of Didymosphenia similar to that reported for the other species by Wang et al., though this remains to be investigated. An anonymous reviewer of this paper described samples in North America with mucilage which seemed to be associated with cells and not the stalks. The general lack of mucilage presumably permits water movement through the colonies, so if it should prove that mucilage is sometimes more important, this would indicate a considerable difference in ecological strategy. However, at least one earlier reference to mucilage and some of the accounts on the internet almost certainly result from confusion in linguistic translation. In the case of Blanco \& Ector (2008), the report of extracellular polysaccharide apparently refers to the stalks, while it is unclear whether Kociolek \& Spaulding (2003), Coyne et al. (2006), Beltrami et al. (2008c) and McNyset \& Julius (2006) mean anything more in their reports of mucilaginous mats, colonies or gelatinous masses.

Individual colonies are hemispherical or more spread out, but increasing abundance leads to the formation of extensive mats. The size of individual colonies varies markedly between sites, but can reach at least $2.5 \mathrm{~cm}$ in height in individual colonies and more when extensive mats are formed. It is unclear to what extent mats develop as the result of released cells becoming attached to the substratum immediately outside an individual colony or by numerous individual colonies coming together as they increase in size. It seems probable that cells are usually removed from the apex of the stalk by currents, rather than gliding through the colony to the underlying substratum, but this needs to be confirmed. When a cell is released at the apex of a branched stalk inside a 
colony, what triggers this release? If it were not sufficiently nutrient-rich, presumably this would reduce its ability to move on a surface and subsequently attach to the substratum. The presence of polyphosphate bodies noted by Moffat (1994) suggests that adequate $\mathrm{P}$ storage may have a role in determining behaviour.

A few studies have included estimates of D. geminata standing crop as cells per unit area. Based on random samples of five rocks on each sample occasion, Kirkwood et al. (2007) described seasonal changes in the Bow and Red Rivers, Alberta, over two years and, though most values were much lower, one on Bow River approached 2,000 cells $\mathrm{cm}^{-2}$. Even higher values occurred (Şahin, 2003) on the lower Yanbolu River in Turkey, where D. geminata density was recorded every month of the year and reached a peak of 7,967 cells $\mathrm{cm}^{-2}$ in June. This may be compared with a theoretical maximum possible of 40,000 cells $\mathrm{cm}^{-2}$, assuming the cells form a single layer and based on a cell diameter of $50 \mu \mathrm{m}$, slightly above the mean of $47 \mu \mathrm{m}$ for valve width of a population reported by Ellwood $\&$ Whitton (2007). Several authors have also reported values for ash-free dry mass. Periphyton dominated by $D$. geminata in the Waiau River, New Zealand, reached a mean of $160 \mathrm{~g} \mathrm{~m}^{-2}$ in 2006 (Kilroy, 2008), while a $D$. geminata mat at one site in the Waikiki River in summer reached $1,047 \mathrm{~g} \mathrm{~m}^{-2}$ (Lagerstedt, 2007). Cell densities in excess of 100 cells $\mathrm{L}^{-1}$ have been reported by several authors from the water column of rivers with dense $D$. geminata growths sampled in summer (e.g. Waikiki River, New Zealand: Lagerstedt, 2007), although studies are lacking on the possible effect of time of day.

Auxospore formation of $D$. geminata was described by Meyer (1929) from Lake Baikal, where huge masses formed in mid-June. The process involves two cells pairing within a mucilage tube prior to sexual reproduction; the cells always pair 'head-to-tail' (Canter-Lund \& Lund, 1995). As one gamete is on a stalk and the other is not, the latter apparently actively seeks out the former. Auxospore formation was noted during early August 2007 in a small tributary near the source of the R. Coquet, N-E England, far upstream from the main growths of the organism (unpublished data). Cells in the immediate vicinity showed marked differences in morphology from typical cells in the main river. This is presumably an example of the diversity of immediate post-auxospore forms well known in other genera (e.g. Geitler, 1932), but apparently not studied in Didymosphenia. Auxospore formation was also recorded for D. lineata (Skabichevsky, 1983), but not (yet) for other species.

\section{Physiology and biochemistry of stalks}

The large dichotomizing stalks are one of the most striking characters of Didymosphenia (Fig. 2) and this extracellular polymer represents a considerable part of its primary production lost to future cell generations once a colony ceases. Several accounts (e.g. Lee, 2008) mention that the stalks comprise over $90 \%$ of the biomass, though it is unclear whether any detailed studies to support this value have been made. The production of so much non-photosynthetic material may be part of the reason why this diatom is restricted to high light conditions (see below) and stalk formation is probably rare in winter. Although the stalks appear morphologically quite similar with the light microscope to the stalks of larger species of Gomphonema, Didymosphenia stalks probably form a greater proportion of the total biomass of a colony. The stalks can therefore be assumed to be especially important for the success of the genus. They reduce competition for substrate surface area (Hoagland et al., 1982) and distance of the cell from the substratum, thus exposing it to higher light and current speeds, and enhancing gas exchange and nutrient uptake (Whitford, 1960). The stalks of cells in Gordale Beck, UK, were reported to be calcified (Pentecost, 2005); his account shows a section of recently formed travertine (tufa) including D. geminata with the frustules still attached to stalks.

Didymosphenia geminata stalks are composed primarily of sulphated polysaccharides with a significant uronic acid and protein content (Gretz, 2008). Monosaccharide analysis showed mainly galactosyl and xylosyl residue and linkage analysis showed mainly 3,4-Gal and 4-Xyl; therefore, the polysaccharide appears to be primarily sulfated xylogalactan. Gretz (2006) suggested that D. geminata stalks have chemical similarities with Cymbella cistula, where the hydrophilic nature of the sulphated hydrogalactan involves ionic cross-bridging. Partial degradation of stalks with several chemical agents showed 
concentric layers of material with differing composition (Gretz, 2008). The hydrated xyloglucan component was surrounded by an outer striated layer resistant to degradation. Enzymatic activity was the most effective means of degrading stalks and Gretz suggested that this might have an application in biocontrol.

Even if it seems unlikely, the possibility should be considered that nutrients might pass from one cell to another via the stalk. However, another role related to nutrients is more convincing, uptake from the environment and subsequent transfer to the cell. The upper parts of D. geminata stalks sampled in early summer showed strong phosphomonoesterase activity when stained with BCIP-NBT (Ellwood \& Whitton, 2007). In addition to the uppermost stalk segment, staining sometimes extended to the upper part of the adjacent segment, but it was most obvious just below the cell. Staining has not been observed at any site in a stalk segment below the uppermost two (unpublished data). Staining appeared to be inside the stalk rather than on its surface (Ellwood \& Whitton, 2007), but this needs to be confirmed, because the stain was supplied at a higher concentration than likely for organic phosphate in nature. Assays with the analogue phosphatase substrates, para-nitrophenyl phosphate, bis-para-nitrophenyl phosphate and methylumbelliferyl phosphate, led to release of (at least part of) the organic moiety to the medium, even if the hydrolysis had occurred inside the stalk. There were marked differences in the ratio of phosphodiesterase:phosphomonoesterase activities during the survey. As a high ratio reflects greater $\mathrm{P}$ limitation in other phototrophs (Whitton et al., 2005), the ratio could probably be used to indicate extent of $\mathrm{P}$ limitation in D. geminata.

The hydrolysis of organic phosphate by the stalk raises a number of questions. One possible way this could aid $\mathrm{P}$ accumulation by the cells would be enzymatic hydrolysis of organic phosphate at the stalk surface, with subsequent release of $\mathrm{Pi}$ to the water and uptake by cells. However, it seems much more likely that the stalks behave in a similar way to the non-photosynthetic multicellular hairs of some cyanobacteria and eukaryotic algae (Whitton, 1988; (Whitton et al., 1991), where organic P hydrolyzed by the hairs is passed to the photosynthetic part of the organism. Presumably, the phosphatases operate under alkaline conditions, which may be one reason why $D$. geminata is associated with higher $\mathrm{pH}$ values, but nothing is known about $\mathrm{pH}$ buffering inside the stalk. Assuming the stalk wall is permeable to organic phosphates, is this merely filtration permitting some molecules to enter or is there some more specialized process? Even if a similar behaviour occurs in other stalked diatoms, can Didymosphenia use larger molecules and is this part of the reason for its success?

Where hydrolysis occurs inside the stalk, inorganic phosphate still has to reach the cell. Ellwood \& Whitton (2007) speculated that it might occur by diffusion, and in this case, energy-requiring phosphate-binding inside the cell would promote the necessary gradient. They also reported that stalks of material from R. Coquet had what appears to be a central tube, which extended further down the stalk than the stained region. It has now been shown using electron microscopy that stalks of $D$. geminata from Stony Gill have a large central reticular region surrounded by an outer much denser layer that stains for phosphatase activity (M. Aboal, S. Marco, E. Cháves, I. Mulero \& A. García-Ayala, Pers. Comm).

Insight to the possible functioning of Didymosphenia stalks may be gained by comparison with other aquatic organisms where phosphatase activity associated with specialized structures and is thought to be involved in hydrolysis of organic phosphates in their environment. Increases in stalk length as a response to phosphate limitation were described for several bacteria by Schmidt \& Stanier (1966). The most detailed account (Ireland et al., 2002) is for Caulobacter crescentus, a widespread bacterium of oligotrophic waters. Here the stalk is an extension of the cell membrane and stalk elongation is stimulated by phosphate starvation. The stalk contains 39 different proteins, including two alkaline phosphatases and a 3 -phytase. The authors concluded that these phosphatases and several other proteins fitted the hypothesis of the stalks playing a role in nutrient uptake.

The stalks of Caulobacter have similarities with the multicellular hairs of some cyanobacteria and eukaryotic algae, where hairs increase in length in response to $\mathrm{P}$ limitation and much, and in some cases, all cell surface phosphatase activity is localized on the hair (Whitton et al., 2005). However, many algae utilize organic phosphate without the development of stalks or hairs, and so it is unclear why activity is localized to these structures in only some algae. 
Ability to utilize widely varying concentrations is one possibility (Whitton et al., 2005). If the main role of stalks in addition to distancing the cells from the substratum is to provide access only to organic $\mathrm{P}$, this represents a considerable diversion of resources to obtaining a particular form of one element. Once stalks have started to form, then the organism would lose its competitive advantage if organic $\mathrm{P}$ is no longer a main component of aqueous P. A key question in understanding the ecology of Didymosphenia is whether the stalks also aid uptake of inorganic $\mathrm{N}$ and $\mathrm{P}$. Dried D. geminata stalk material from Rapid Creek, S. Dakota, has been shown to bind phosphate (Maurer, 2008), though it is unclear how relevant this is to live material. Phosphate was adsorbed at a rate of $2 \mathrm{mg} \mathrm{P} \mathrm{g}^{-1}$ dried alga from a solution with $100 \mathrm{mg} \mathrm{L}^{-1} \mathrm{P}$ over a 20 -h period. Adsorption did not occur when the stalk material had been washed with EDTA prior to the experiment, which led to the release of iron to the medium; the author suggested this element contributed to the binding of phosphate.

Stalks are highly persistent in situ and when material is transferred to the laboratory. The stalks of colonies which had only few cells persisting subsequent to mechanical damage in a drainage stream entering Lough Inagh, Connemara, Ireland (see below), and kept in the laboratory for two years at room temperature were little changed morphologically-merely a more fibrous appearance (unpublished data).

\section{Floristic records and providing evidence for change}

Survey methodology

Before reviewing the literature on the occurrence of Didymosphenia geminata, it is important to consider how records have been made. Ideally each record should be assessed individually, but some general comments can be made. Early naturalists such as Hassall (1845) collected the alga because it was visually obvious and then used microscopy to study cleaned frustules. Many subsequent reports were based entirely on cleaned frustules, but more recent records often combine field and microscopy observations. Fortunately, it is a large and distinctive organism whether viewed macroscopically or under the microscope, and so most records can be treated as reliable. However, some other diatoms forming colonies, such as several Cymbella species and Hannaea arcus, might be confused macroscopically with smaller colonies of Didymosphenia, and so it is important to include microscopy.

If the distribution of Didymosphenia is localized at a site, standard sampling methods such as the use of a toothbrush to scrape selected surfaces (Round, 1993 and subsequent developments of this methodology for routine monitoring) may fail to record the organism, unless checks for macroscopically visible colonies are also done; two instances of this are known to the authors. Much depends on the extent to which its distribution at a site is localized, as has been shown for a river with hyporheic flow (Wyatt et al., 2008: see below), and, as seems probable, at the most upstream sites in a catchment. Spaulding (2008) commented that standard protocols for measuring diatom abundance underestimate both presence and relative abundance of $D$. geminata. In addition, records based only on cleaned frustules must be interpreted with caution, because of the possibility that dying cells or empty frustules originated upstream. Unless the species is abundant in such a sample, all that can be concluded from its presence is that it either grows at the site or somewhere in the upstream catchment. Neutral red stain may be used to check whether or not cells that may have been damaged are still alive (Kilroy, 2007a).

Cary et al. (2007, 2008) report on a molecular method of detection based on PCR amplification of $18 \mathrm{~S}$ ribosomal RNA. Tests done with $D$. geminata from a range of countries indicated that the method is specific for D. geminata, though the tests apparently did not include other Didymosphenia species. The detection threshold for the sample used for calibration was $1 \mathrm{pg}$ and this was equivalent to $0.1-1 \mathrm{D}$. geminata cells in the sample, and so the method is very sensitive. However, it remains to be tested thoroughly under conditions where D. geminata is known to be present in a catchment, but only in very low numbers.

Asia

The literature summarized here and many more brief mentions on the internet show that Didymosphenia is widespread in subarctic and temperate Asia (Fig. 3). Based on material from Lake Baikal, two localities in 


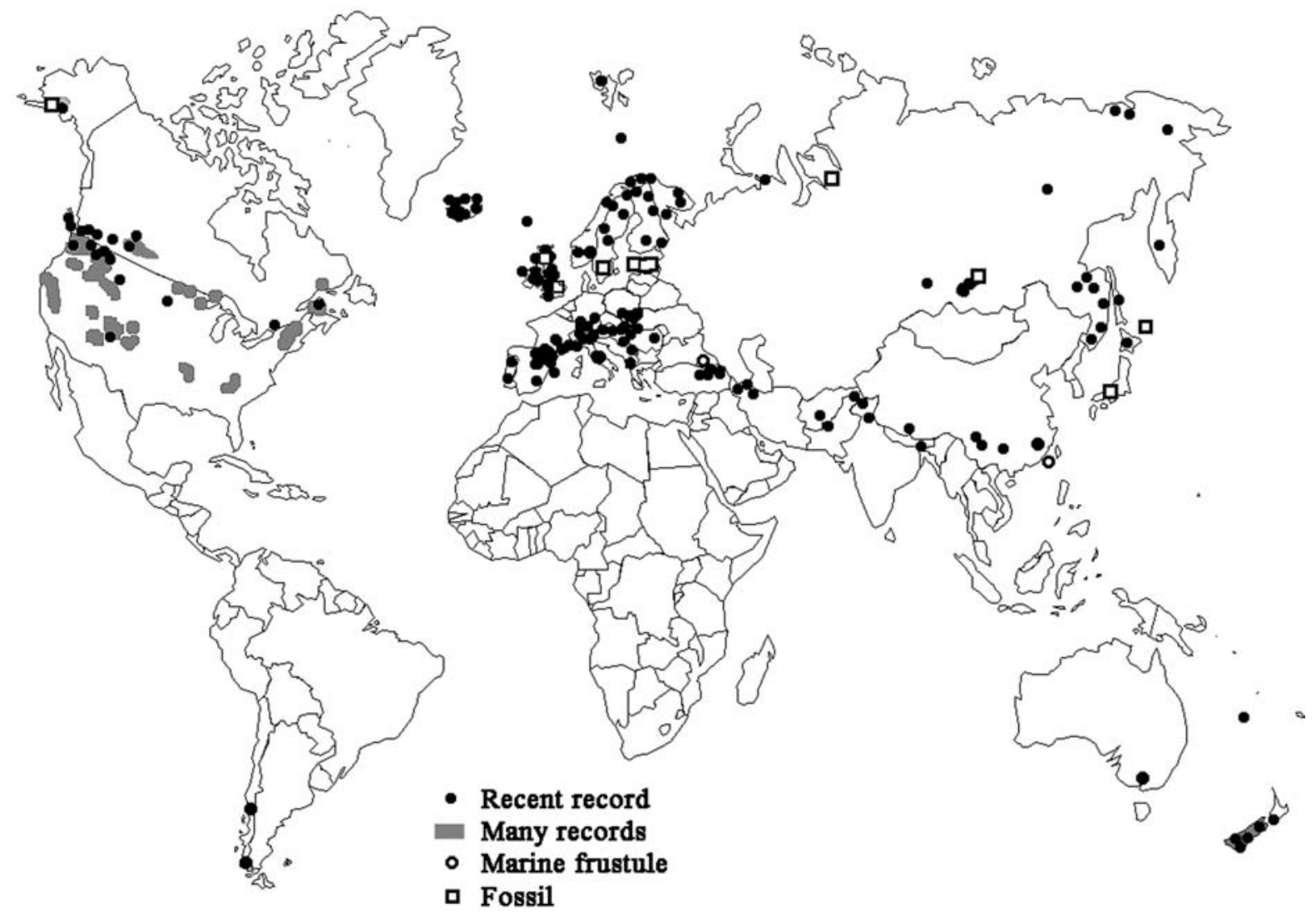

Fig. 3 World-wide distribution of records for D. geminata (including forms). Records indicated by symbols are mentioned in the main text or included in the following papers: Asia: Barinova et al. 2008 (Rudnaya River, Russia); Lange-Bertalot \& Genkal, 1999 (Yugorsky Peninsula, Siberia); Nikulina et al. (2008) (Russia, Far East). Europe: Ács et al. 2003 (R. Enns, Austria); Johansson, 1982 (Jämtland, Sweden); Koksvik \& Reinertsen, 2008 (Alta River, Norway); Kawecka \& Olech, 2004 (streams by Lake Marjajärvet, Finnish Lapland); C. Gudasz in Kilroy (2004) (Romania); B. Kawecka, unpublished data (River Spöl and Val da l'Aqua, Switzerland); Komulaynen, 2008 (Teno River, Finland); Kawecka \& Eloranta, 1987 (Finland); Metzeltin \& Witkowski, 1996 (Baren Island, Svalbard, Norway); Novikmec et al. 2007 (eastern Carpathians, Slovakia); Szabó, 2004 (R. Tisza, Hungary); Robinson \& Kawecka, 2005 (Macun Lakes region, Switzerland). Most of the records for France are based on some (Héribaud, 1893;

China, Lake Kartuk, Alaska and Lake Superior, Stoermer et al. (1986) concluded that Didymosphenia is most differentiated with respect to its morphology in Siberia. There is a long history of studies in Lake Baikal, including a detailed account by Skvortzow \& Meyer (1928). Because of the importance of Lake Baikal, the various taxa reported are mentioned here,
Comère, 1894; Hustedt, 1938; Cazaubon, 1988; ASCONIT, 2007) of the many references for the country provided by S. Blanco and L. Ector. Where papers include many records for one region, only a limited number of symbols are shown. North America The regions in N. America and New Zealand with many records in 2007 indicated by shading are based on the maps in Kilroy (2008) and Spaulding (2008). The references quoted and cited by the latter are: Foged (1981), Manguin (1960), Nelson et al. (1973), Prescott \& Dillard (1979), Stoermer (1980) and Zingmark (1969); Bowman et al. (2005) (Canada, Bow \& Athasbasca R.). The additional symbols shown in the figure for the same region relate to papers quoted in the present review. Further reports for Canada (not on map) include MacClement (1915), Lowe (1924), Smythe (1973), Duthie \& Socha (1976), Moore et al. (1978), Moore (1979) and Sheath \& Steinman (1982)

but there is an urgent need for critical study to clarify the situation.

Foged (1993) reported five taxa, D. dentata var. subcapitata and D. geminata type and three of its varieties. The shape and dimensions of one of these varieties, D. geminata var. stricta fo. baikalensis, suggest that it may have been D. clavaherculis (syn. 
D. geminata var. stricta). Metzeltin \& Lange-Bertalot (1995) suggested nomenclatural changes for the other three taxa: D. geminata morphotype subcapitata for D. dentata var. subcapitata according to Foged and D. curvata for both D. geminata var. baikalensis fo. curvata and D. geminata var. sibirica fo. curvata according to Foged. Flower et al. (2004) listed three main morphotypes of $D$. geminata (sensu lato) in shallow water epilithic communities: (1) narrowly capitate form with values up to $130 \mu \mathrm{m}$ long; (2) smaller form; (3) relatively broad, sometimes curved, form with valves up to $150 \mu \mathrm{m}$ long. Morphotype 2 seemed to correspond with $D$. sibirica, but the others did not fit precisely with taxon descriptions in Metzeltin \& Lange-Bertalot (1995). One of the most conspicuous deepwater benthic taxa, D. dentata (Dorogostaisky, 1904), is thought to be restricted entirely to the lake (Kociolek et al., 2000; Flower, 2005). Kociolek et al. argued against it being conspecific with $D$. geminata because of valve shape, the presence of marginal spines and the lack of stigmata.

Didymosphenia is frequent along parts of the Lake Baikal shore (D. Jewson, pers. comm.). D. geminata occurred as an epilith at $0.3-1.3 \mathrm{~m}$ depth at Bolshiye Koty Bay, where there are high rates of near-bottom currents and constant resuspension of fine clastic material (Kravtsova et al., 2004). In a further study in the same area, it was one of 23 diatom species in the community developing on bricks placed in March at 2-5 m depth (Kravtsova et al., 2006). Kawecka (in press b) reported four taxa in September 2006 from the Sljudjanka River in the southern part of the Baikal catchment: D. clavaherculis, D. geminata morphotype geminata, D. geminata morphotype capitata, D. geminata morphotype subcaptitata. Among other studies from Russia is one on the periphyton at a midstream site in R. Yenisei downstream of the Krasnoyarsk Hydroelectric Power Station, which included detailed observations on the one to three species forming the dominants every month from March 2001 to September 2006; D. geminata was one of the dominants on seven occasions (Kolmakov et al., 2008). Many other reports of D. geminata from Russia show how widespread it is. T. Nikulina (pers. comm. to B. Kawecka) found it in the Primorye Region, Kuril Islands and Sakhalin Island and holds information from others for: north-east (R. Kolima, R. Anadyr, Lake El'gygytgyn); lakes, river and springs on Kamchatka Peninsula; south-east (R. Amur, R. Zeya; rivers, small springs and reservoir in Primorye Region e.g. R. Razdolnaya). There is also a report from Japan in the R. Izari, Hokkaido (Tuji \& Nergui, 2008).

Among the many records for China, there are accounts of huge growths in the Kanchou region (Skvortzow, 1935) and for samples from the Hengduan Mountains (Li et al., 2003) and the Mount Everest (Jololungma) region collected in 1966, but reported by $\mathrm{Li}$ et al. (2004). The last included D. geminata in a list of 'widely distributed and dominant' species. Although Hirano (1966) reported it from northern Pakistan (Naz Bar at 2,550 m), Bhatt et al. (2008) concluded that at least some occurrences in 2002 and 2003 in rivers of the Indian Himalayas may have been modern introductions. It was found in the rivers sampled in Jammu \& Kashmir and Himachal Pradesh in the west, and in Sikkim in the east, but not in four central Himalayan rivers. Rivers with $D$. geminata also had brown trout, an exotic here, while those without the diatom had no trout. Records from other countries provide geographical links to Europe. Metzeltin \& Lange-Bertalot (1995) list records for N-W Pakistan and Afghanistan and it was abundant at three river and stream sites in $\mathrm{N}-\mathrm{W}$ Iran (Maragheh, Ahar, Sahand) in recent surveys (I. Atazadeh, pers. comm.).

Records for Turkey all come from mountain regions in the N-E, though this may simply reflect the location of the researchers. It was a common epilith in two lakes sampled in 1988, one free of snow cover for only four months (Şahin, 2001), and two small lakes covered in ice from December to April (Şahin, 2000). In the two small lakes, Aygir and Balikli, D. geminata was one of the four most common epilithic diatoms (Şahin, 2000); though no data were reported for $\mathrm{P}$, the concentrations of all other ions were low or very low. Its occurrence in the plankton of Karagöl Lake was attributed to strong wind action on the sediments (Kolayli \& Şahin, 2007). There are also reports for San river (Kolayli et al., 1998), R. Değirmendere (Kara \& Şahin, 2001) and the lower Yanbolu River (Şahin, 2003), all of which drain the same region. D. geminata was recorded every month of the year in the latter, reaching a peak of 7,967 cells $\mathrm{cm}^{-2}$ in June.

In spite of the many reports from Asia, the worldwide map shown in Fig. 3 almost certainly 
fails to include records from other regions in Russia and perhaps also Ukraine published only in more local journals.

\section{Europe}

There are sufficient records to indicate that D. geminata was widespread at least 150 years ago in several European countries. Hassall (1845) found it in mountain streams in the British Isles at sites in Ireland, Scotland and Wales, while Smith (1853), who gave further examples, including one in the English Lake District, reported it as not uncommon in subalpine streams. (Victorian naturalists often called fast-flowing streams in hilly districts 'subalpine'.) It was reported in 1851 for the R. Coquet, which drains rough grassland overlying serpentine rocks in the Cheviots, N-E England (Tables 2, 3); mass growths have occurred in many years on one stretch since at least the late 1950s (Whitton \& Ellwood, 2008). It was also recorded in 1977 at three of six sample sites on R. Tees, a river draining peaty soils overlying limestone (Holmes \& Whitton, 1981). It is now frequent in many upland rivers in the UK, including others draining the Cheviots, such as Megget and Yarrow (website information from J. Kinross, Napier University, UK) and many sites in the Malham, Yorkshire, region (A. Pentecost, pers. comm.). However, it was not recorded in a survey aimed at producing a comprehensive list of the diatoms of Clare Island off the west coast of Ireland (Sims, 2007). As many streams on this island combine peat and limestone drainage, conditions that favour D. geminata elsewhere (see below), it may represent an area where the diatom has not yet invaded, but likely to do so soon.

In the case of Norway, Lindstrøm (2008) state that the first record for the R. Tana (in the N-E) was in 1868 and it is still common there; the river is one of the country's most important salmon rivers. They also quote a report by Schmidt-Nielsen \& Printz (1915) of profuse growths in the R. Dramselva (S-E Norway) in April 1911. In R. Glåma (S. Norway), it not only formed dense growths on boulders during the warmer months, but continued during the winter in rapids that were not ice-covered (Skulberg 1984). Surveys in east Fennoscandia, N-W Russia, indicate that $D$. geminata is one of the most widespread algae in river periphyton, being recorded in 27 of 66 rivers sampled only once during a short period in late summer ( $\mathrm{S}$. Komulaynen, pers. comm.). It was also one of 12 diatoms listed as 'the most common to exhibit substantial densities' in R. Teno, Finnish Lapland (Komulaynen, 2008). Although once considered an endangered species in Germany (see below), 'it has been reported since the early 1990s in rivers in South Germany, like the Isar and the Inn. For the past 510 years it has appeared in big quantities, sometimes covering all the river bed' (G. Hofmann, pers. comm. to G. Friedrich, January 2009).

Records for northern Italy start with Brun (1880) and Bonardi (1888), but it was not mentioned in earlier reports from the Trentino Region where it now occurs (Beltrami et al., 2008c). Beltrami et al. (2008b) quote other earlier records from Italy, including flowing waters in the 1920s (Giaj-Levra \& Abate, 1994) and five major lakes in the north of the country between 1883 and 1925 (database quoted by authors). Based on the use of diatom indices in rivers of this Region, Beltrami et al. (2007) grouped $D$. geminata with five other diatoms as mesoeutrophic, whereas Beltrami et al. (2008b) concluded for the same region that it occurred in rivers with low pollution (Table 2). Beltrami et al. (2008a) also report records for R. Drava, a R. Danube tributary in N-E Italy. There are now reports for almost every country in northern Europe and most in southern Europe (Fig. 3, Table 2). Records for Portugal and Spain, which are summarized by Blanco \& Ector (2008), include the island of Mallorca in the Mediterranean Sea (Margalef, 1953). Overall, however, there are many fewer records for the parts of Europe with a more Mediterranean climate and this seems to reflect a real difference in abundance rather than fewer surveys.

In Poland, two reports from the 1960s mention D. geminata in streams and rivers draining the Tatras, though apparently with low abundance (Siemińska, 1964; Kawecka, 1965). Since the 1980s, however, there have been an increasing number of reports of abundant growths from southern Poland, including R. San (Kawecka \& Sanecki, 2003) and from different areas such as R. Wisła and its tributaries (WIOSKraków, 2000) and the R. Czarna Orawa catchments (Noga, 2003). In the study by Noga, occasional cells were found at more upstream sites with oligotrophic waters, but the most abundant growths were well into the mesotrophic zone. Where data are given, the $\mathrm{pH}$ 


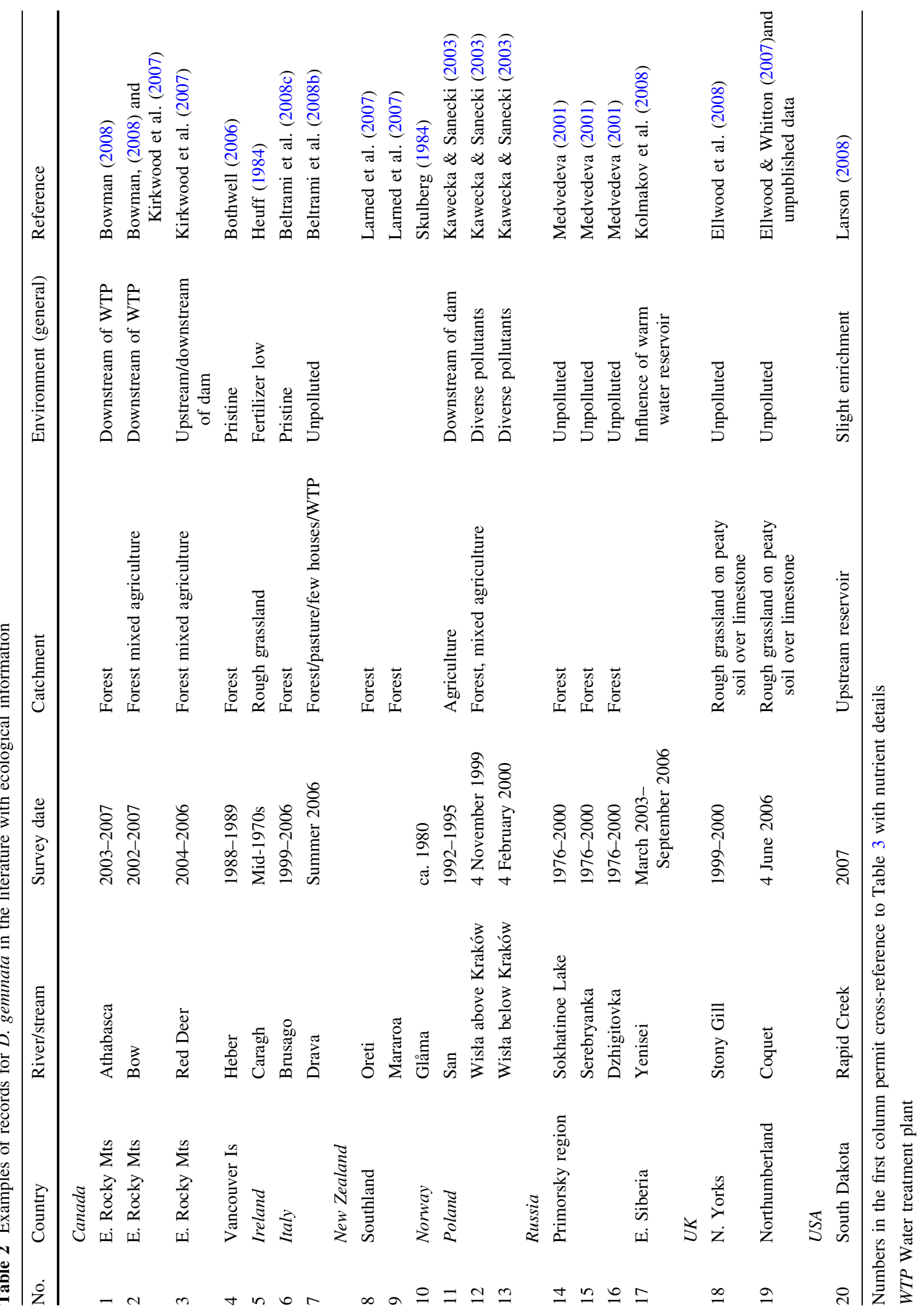




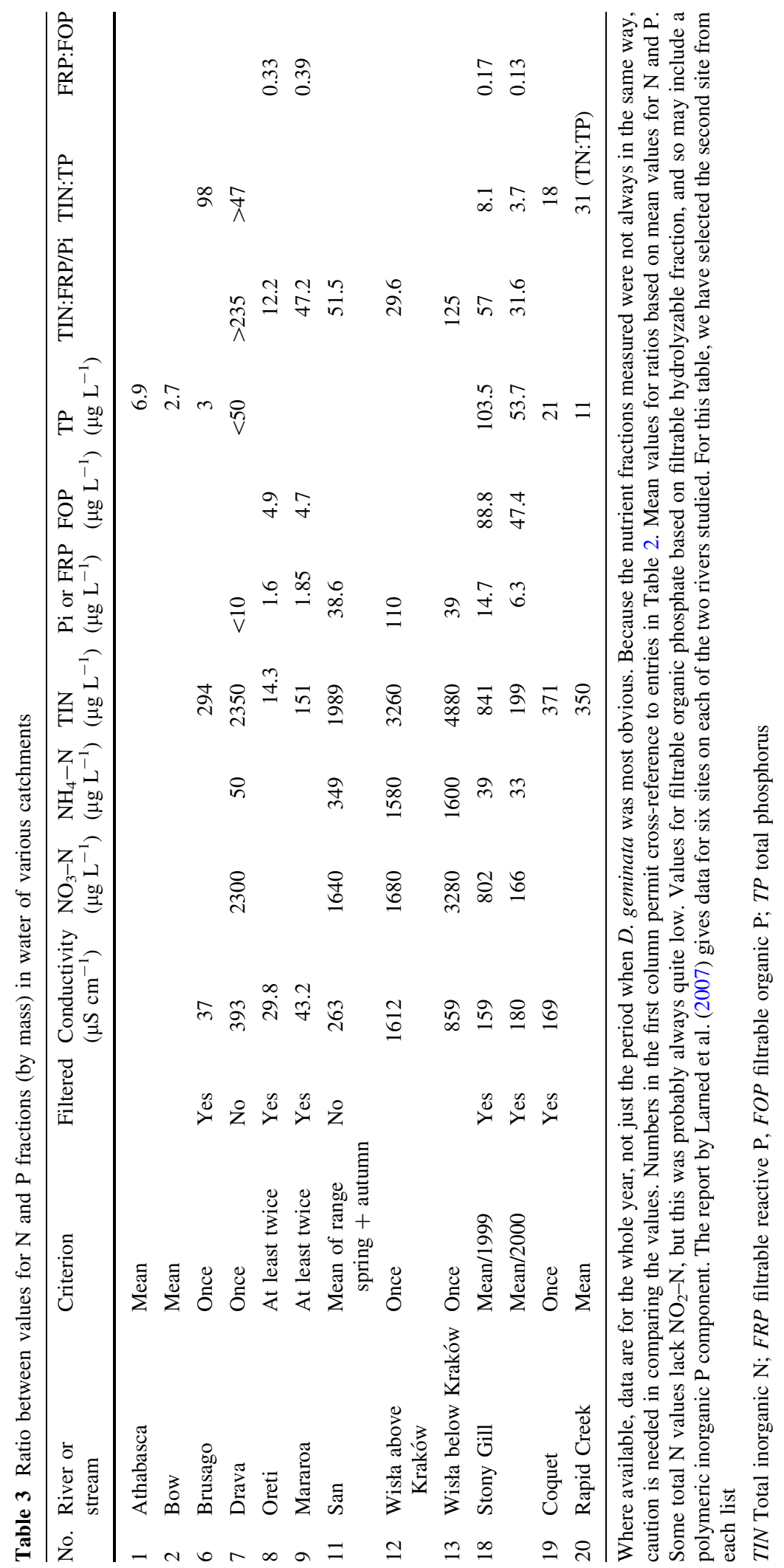


was 7.5-8.9; the species was absent from small, deep streams draining peat. D. geminata also formed large growths in 2002 downstream of a recent dam on the R. Dunajec (Mrozińska-Broda \& Czerwik-Marcinkowska, 2004).

Other countries in Europe with recent spreads include Czech Republic (Gágyorová \& Marvan, 2002a, b), Hungary (R. Tisza, Szabó et al., 2005), Serbia and Montenegro (Subakov-Simić \& Cvijan, 2004; Subakov-Simić et al., 2006) and Iceland (G. S. Jónsson et al., 2000; I. R. Jónsson et al., 2008, in press). However, a large project on epilithic diatoms of rivers in Hungary in 2005 found that, overall, the species was rare: only six specimens (four localities) from 400 rivers (J. Padisak, pers. comm.). In Serbia, it was first observed in the lakes of Šar Planina mountain, but has subsequently been found in many rivers and canals, including the Danube by 1997 and R. Tisza by 1999 (quoted by Subakov-Simić et al. but without references), where it is found frequently in the entire course of the river. Its selection as one of the six diatoms to be illustrated by Cadjo et al. (2005) in an account of the phytoplankton of the Danube suggests its present abundance there. The evidence for increases in Iceland is especially convincing. It was first reported in the R. Hvita in West Iceland in 1994, though the growth was obvious enough for local residents to notice it in 1992 and increased in the following years. A national survey in 2006 of lowland streams, mainly in northwest and eastern Iceland, showed that it now occurs in parts of the island where it did not occur in a 1997 survey. Nevertheless, I. R. Jónsson et al. (2006) concluded that the species had become less abundant in some of the rivers where it had first been reported, perhaps indicating that the pioneering stage of colonization was over.

The discovery in 2004 of a previously unknown species, D. tatrensis, in five streams and rivers in Poland and Slovakia by Mrozińska et al. (2006a), all with $D$. geminata at the same sites, raises the possibility that records for this or other species of Didymosphenia may sometimes be included within records for $D$. geminata. The two species not only occurred in the same stretches of several streams in the Dunajec catchment in southern Poland and Slovakia (Mrozińska et al., 2006b), but also on the same rock at several sites on R. Białka, which is also in the Wisła (Vistula) catchment (unpublished data).
North America

Historical reports for USA are listed by Spaulding et al. (2008), who comment that they are primarily taxonomic or floristic; the quoted studies are included in the legend to Fig. 3 in the present review. The account by Spaulding et al. also includes a map showing a few sites in Canada. The records for the USA come from many regions, though none from the southernmost states. Recent surveys in the USA based on 4,750 samples indicated D. geminata at 308 sites. A total of $20 \%$ Colorado mountain streams and $6 \%$ western United States streams were estimated to contain D. geminata. In Rapid Creek, South Dakota, where it was first reported in 2002, it has since 'displayed characteristics of an invasive species' (Erickson \& Shearer, 2006; Shearer \& Erickson, 2006).

The checklist of freshwater algal records for Canada by Stein \& Borden (1979) lists six references with records for D. geminata (all as Gomphonema acuminatum). All appear to be for British Columbia, the earliest being Lord (1866), with later ones for Okanaga Lake (Clemens et al., 1939), Kootenay Lake (Ennis, 1974) and the Fraser River (Ennis, 1975; Northcote et al., 1975; Stein, 1975). D. geminata was found in over $80 \%$ of 50 sites in 18 rivers in the South Saskatchewan River Basin $\left(101,720 \mathrm{~km}^{2}\right)$ in recent surveys in Alberta, Canada with dense growths at almost half of these sites (A. E. Kirkwood, pers. comm.). Extensive mats have been recorded in many other North American rivers in recent years, some local researchers regarding them as natural, while others as probable or certain invaders. A report on a Canadian stretch of the Columbia River stated that dense mats, which were visible in some years, 'are considered a natural occurrence rather than a symptom of distress' (Columbia River Integrated Environmental Monitoring Program, 2005).

Whatever the status of D. geminata in the Columbia River, many other accounts for North America record a recent increase, even if the organism had been there previously. Filamentous algae and D. geminata together covered less than $10 \%$ substrate during 1998 and 2003 on the upper East Boulder River, but $D$. geminata formed a $100 \%$ cover by late summer at several sites in 2004 (Beeson \& Mitchum, 2006). 'Blooms' of D. geminata in recent years were reported for Kootenai River downstream of the Libby 
Dam, Montana (Eichman et al., 2006). The first growths to be reported in Québec were in 2006 in the Matapédia River, where they eventually extended along about $30 \mathrm{~km}$ of the river, covering up to $100 \%$ of the substratum with a carpet about $2.5 \mathrm{~cm}$ thick (Whoriskey, 2008). Growths were less in 2007, probably due to higher water levels (Simard \& Simoneau, 2008).

The presence of new or increased growths in North America was apparently noted first on Vancouver Island, British Columbia, where large growths began appearing in the Heber River in 1988 and 1989 (Sherbot \& Bothwell, 1993; Bothwell et al., 2006). Within five years, D. geminata had spread to 12 catchments on Vancouver Island and was abundant in nutrient-poor rivers previously known to have very low algal biomass (Fig. 4). Studies on the potential impact of solar ultraviolet radiation proved negative. The authors suggested the possibility that the changes in the 1990s might have resulted from an invasion by a new strain of $D$. geminata to Vancouver Island streams associated with intense recreational pressure in the 1980s. For unknown reasons, the D. geminata growths in many of the Vancouver Island rivers waned between 1996 and 1999, and by the 2000s, they were no longer reported from many of the impacted rivers (Bothwell et al., 2008).

Kumar et al. (2009) provided a modelling study to predict the potential habitat distribution of

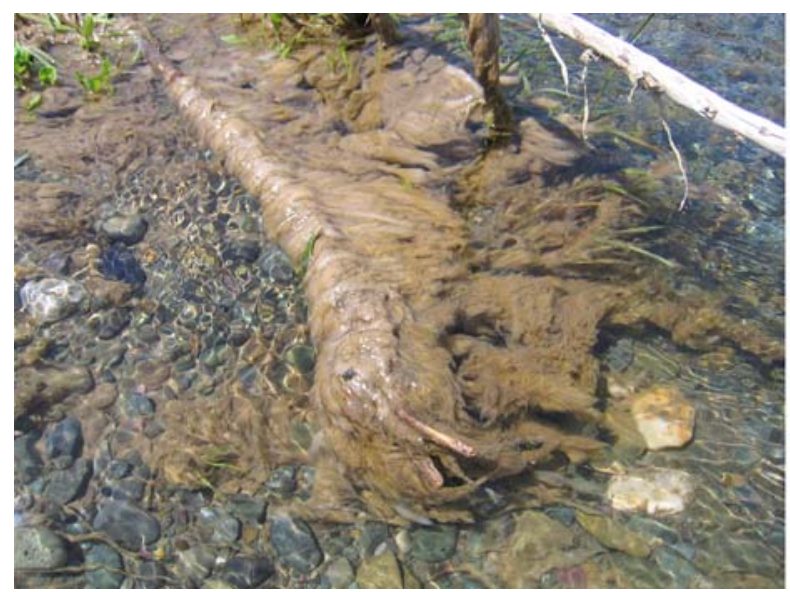

Fig. 4 Left-hand River Mararoa, New Zealand, January 2009; typical appearance of large growths at the stage when stalks become very obvious. Right-hand River Puntledge, Vancouver Is, September 2007; although growths were past their peak for the season, D. geminata still formed the overwhelming
D. geminata in continental USA. This considered 39 environmental variables, but all related to climate and topography, though they recognized that other factors may be relevant to the range expansion and formation of nuisance growths. They concluded that their model was able to predict the potential habitat distribution in continental USA without the use of water chemistry. The most suitable habitats were predicted to occur in the western USA, in relatively cool sites, and at high elevations with a high baseflow index. However, the factors influencing regional-scale distribution may be addressed more appropriately by including information on anthropogenic factors that can influence the diatom and spatially explicit data on water chemistry.

\section{Southern hemisphere}

Although some recent literature claims that Didymosphenia was absent in the southern hemisphere until recently, there are a number of earlier records. Both of the two records for D. geminata in Chile (Asprey et al., 1964; Rivera, 1983) are illustrated (L. Ector, pers. comm.). The former was based on material collected by J. E. Furet and studied in the UK when one of the authors of their paper was involved in a project on D. geminata; the matter was mentioned to one of the present authors (B. A. W.) during a visit to the laboratory at the time. In view of the fact that the

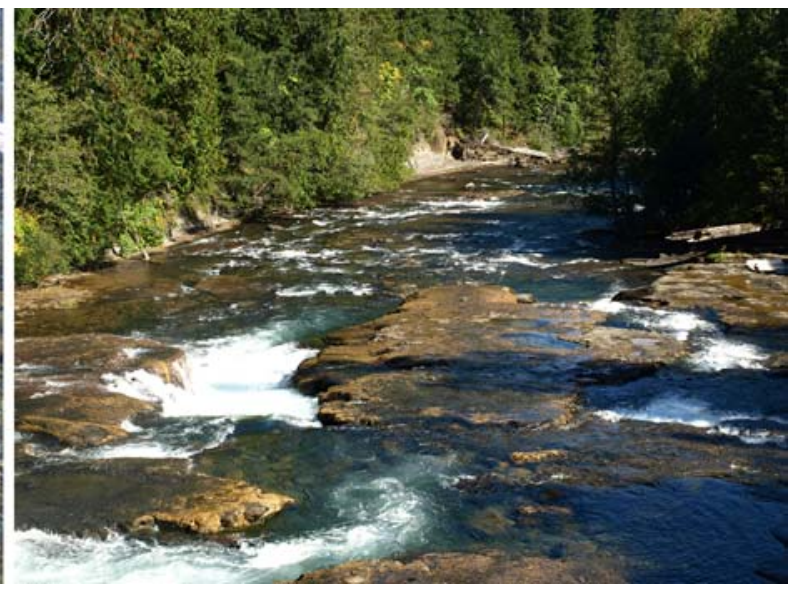

proportion of algal biomass. Deep brown colour is due to submerged colonies, rich brown to colonies in wet film and pools on exposed rock surfaces; paler colours largely due to dried alga 
majority of records for $D$. geminata in other parts of the world are for flowing waters, it should be noted that a recent record of literature of freshwater diatoms in Chile (Ramírez, 2006) lists only one study on flowing waters and that for epiphytes.

In the case of Australia, the checklist by Day et al. (1995) includes one report (as Gomphonema geminata). This is based on a short list of algae found in a pond at Oakleigh, Victoria, in August 1886 (Watts, 1886). There is at least one report for New Zealand (Mather, 1928) prior to the recent mass growths and the species was included in the checklists of New Zealand freshwater algae by Chapman et al. (1957) and Cassie (1984); this record for the North Island is for a ditch in the Hutt Valley at the southern end of North Island. In the case of a record from New Caledonia (Manguin, 1962), the organism was initially treated as a variety of $D$. geminata, but recognized as a species by Metzeltin \& LangeBertalot (1995). The frustule was illustrated by Manguin, who found it in the N-E of the island on moss in a stream overlying serpentine. However, doubt was subsequently raised about its status by Kociolek \& De Reviers (1996), who could not find the original specimen among Manguin's samples.

Although these are all parts of general floristic studies and therefore open to the risk of error, there is no more reason to question them more than most other records in the literature. It will require thorough field surveys in likely habitats, together with checks on old samples and records, combined with modern molecular studies, to establish whether D. geminata really is rare in much of the southern hemisphere apart from its recent expansion in New Zealand.

Recent interest in the southern hemisphere has, however, focused on New Zealand, where unusual algal mats were reported from the Lower Waiau River, South Island, in October 2004 (Kilroy, 2008). Biggs et al. (2006) claimed these as the first record for Didymosphenia in the southern hemisphere, and Kumar et al. (2008) repeat that its initial discovery in New Zealand was in 2004. By September 2005, D. geminata was noted in several rivers in central and northern South Island, often with mass growths, and had subsequently been reported for about 53 South Island rivers by October 2007 (Larned et al., 2007), though the only record for North Island is still that by Mather (1928). The effect on the Lower Waiau River is evident in the large increases since 2004 in ash-free biomass per unit area at a site monitored since 1993 (Kilroy, 2008); based on the data shown, these are at least 20 -fold.

\section{Occurrence in standing waters}

Most records for standing waters are for shallow epilithic communities, such as in Windermere, the English Lake District (Godward, 1937), the Turkish lakes mentioned above and Lake Sokhatinoe, one of the Sikhote-Alin biosphere reserve lakes in East Russia (Medvedeva, 2001). However, Didymosphenia occurs deeper in Lake Baikal (Flower, 2004), including a record at 15-20 m (Pomazkina et al., 2008), presumably favoured by high light penetration. In Morskie Oko lake, Tatra Mts, Poland, it was epiphytic on Potamogeton sp. at $10 \mathrm{~m}$ depth (Kawecka, 1966).

There are also records of $D$. geminata cells from sites which differ markedly from the sites described above and which it seems unlikely could have been introduced accidentally by the researcher. A single live cell was present in a 15-m depth sample in May 2006 in the deep crater lake Lake Albano, near Rome, Italy (unpublished data); the boat used had been in lotic waters in central Italy, though there are no records of $D$. geminata for this region. Carter (2007) recorded a single cell from a lowland pond in Yardley Chase, Northamptonshire, southern England. This pond is highly calcareous, unpolluted and relatively isolated from agricultural land; the cell was epiphytic on the floating liverwort Ricciocarpus natans. The site is several hundred kilometres from rivers or lakes where typical occurrences of D. geminata occur. Although the pond is used for police and military training and the possibility of a cell being introduced from elsewhere cannot be ruled out, this seems unlikely. There are also several marine plankton records, which are presumably due to frustule(s) washed downstream by rivers: South China Sea between Taiwan and Hong Kong (http://www.life.xmu.edu.cn/diatom/diatomphoto/ Main\%20Menu/List.htm); Black Sea coast of Turkey (Feyzioğlu \& Seyhan, 2007).

Year-to-year differences

Interpretation of observations on D. geminata in a particular river are complicated by the fact that the population can change from mass growth to near absence within short periods and that seasonal 
patterns vary from river to river and from year to year, as noted by Lindstrøm \& Skulberg (2007) and in brief mentions by many other authors. In the R. Dunajec, Poland, where it was mentioned by Siemińska (1964), but not included by Kawecka \& Szczęsny (1984) in a detailed list from the river, there have since been periods when it was abundant and then could not be found (Mrozińska-Broda \& Czerwik-Marcinkowska, 2004), though it was quite abundant in 2007 (B. Kawecka \& B. A. Whitton, unpublished data). In Stony Gill, N-E England, where it had been frequent for a number of years when studied in 2000 (Ellwood \& Whitton, 2007), it could not be found in 2006, but was obvious in 2008 (unpublished data). It is unclear whether populations at the edge of lakes and reservoirs show such marked differences from between years.

Fossil records

There are records of Didymosphenia in lake sediment cores, but insufficient to comment on possible longterm changes. The University College London database has many records of its occurrence in Lake Baikal cores and one for Lake Menteith, Scotland (M. Hughes, pers. comm.; all listed as D. geminata, presumably sensu lato). It is also reported from sediments in Lake Lama, central Siberia, sediments (Kienel \& Kumke, 2002) and from Iturup Island in the Kurile Islands (Razjigaeva et al. 2002). Among the most detailed reports are those (all D. geminata) for northern Estonia made by A. Heinsalu (pers. comm.). These include several 11,400-11,300-yearold records for two sites (Lake Rummu and Rae Basin, now a bog), when they were part of the initial freshwater Yoldia Sea phase of the Baltic Sea basin, and several approximately 9,500-year-old records from calcareous silt in what was then a freshwater lagoon isolated from the Baltic Sea (Kõpu basin, Island of Hiiumaa), but now a bog. There is also a record in the early Holocene from the other side of the Baltic in south central Sweden (Hedenström \& Risberg, 1999). An undated post-Tertiary sand stained with peaty residue below a layer of alluvial soil not far from the mouth of a valley entering Loch Fine, Scotland, had a mixture of marine and freshwater species, including D. geminata (Gregory, 1857). A study of a sediment core taken in 2003 from Naknek Lake, Katmai National Park, Alaska, found that $D$. clavaherculis was present at a constant abundance during the previous 786-year period (Hermann et al., 2008). Brooks River, which drains into the lake, currently has $D$. geminata growths.

In contrast to these species, which also occur as living organisms, D. fossilis has only been reported from the Yatula Deposit, Okayama Prefecture, Japan (Okuno, 1944). The holotype was lost in the Hiroshima atomic blast, but a photograph surviving from Okuno's records and obtained by Tuji (2004) was designated as a lectotype. The organism differs from living material in lacking a capitate structure.

\section{Environmental factors}

Physical factors

\section{Flow and current speed}

Various authors have reported on the features of sites with $D$. geminata, though the accounts sometimes differ, perhaps because they are based on different regions. Nevertheless, there is general agreement with Canter-Lund \& Lund (1995) that it favours rocky places where there is plenty of water movement, such as turbulent rivers and the wave washed shores of lakes. Lindstrøm \& Skulberg (2008) reported the preferred river habitats in Norway to be shallow riffles with coarse stable substratum and a steady flow regime.

Stream regulation resulting in reduced flooding and a more constant flow tends to promote build up of biomass of D. geminata. Several rivers in Poland where D. geminata has sometimes been abundant (e.g. Dunajec, San) are downstream of dams (Kawecka \& Sanecki, 2003). Kilroy (2008: quoting a report by Kilroy et al. (2007a)) stated that 'lake influence' (presumably including reduced flow variability) was the most important factor influencing both percent cover and mat thickness and some of the other reports from rivers mentioned above mention growths downstream of dams. A study (Kirkwood et al., 2007, 2008) of the Bow and Red Deer rivers in southern Alberta, Canada, showed a significant negative relationship between $D$. geminata biomass and mean discharge $\left(r^{2}=0.30\right)$ and it was concluded that flow regime rather than proximity to dam outflows probably determines this. Several authors (Kirkwood 
et al., 2007; Kolmakov et al., 2008) have pointed out that dams control other factors beside flow, such as modifying the temperature regime and, especially where deep water is released to the river, the water chemistry, almost certainly including the nutrient fractions.

The thickness of mats may not only be affected by removal in floods but also favoured by low current speed, as suggested for other diatom communities by Lamb \& Lowe (1987). The sites with conspicuous growths in the UK reported by Whitton \& Ellwood (2008) have little or no flow regulation by dams and undergo large, seasonally irregular, changes in flow, though none ever dry completely. Perhaps, flow regulation is less important in the more temperate British Isles, where streams are much less often subject to very high flows in spring after snow melt than under the hydrological conditions of a continental climate. High flows may also differ in their effects depending on the suspended matter load. The study by Kirkwood et al. (2007) gives some indication of this, because sites with $D$. geminata showed a lower coefficient of variation not only for flow but also for lower turbidity. As a result of upstream excavation of the streambed and subsequent downstream deposition of sediment, a site in an inflow stream to Lough Inagh, Connemara, Ireland, with abundant D. geminata in May 2006 had lost many colonies a month later and almost all cells from the stalks of the remaining colonies (D. M. John and B. A. Whitton, unpublished data). Some of the remaining cells showed obvious phosphatase activity at the surface when exposed to BCIP-NBT staining, presumably as a result of cell damage.

A study of the effects of hyporheic-surface water exchange on benthic algal communities in an alluvial stretch of the Middle Fork of Flathead River, Montana, showed significant differences between upwelling versus downwelling and neutral exchanges sites (Wyatt et al., 2008). While Stigeoclonium sp., Zygnema sp. and Hydrurus foetidus were abundant at the former, an assemblage of diatoms attached to, or in close association with the stalks of Didymosphenia geminata were the most abundant taxa at the latter (see below). Based on previous studies of the river, Wyatt et al. considered the upwelling water to be more nutrient-rich than the downwelling water. A detailed study of nutrient fractions and transport on this river would add considerably to the understanding of $D$. geminata ecology, because all the algae for this site listed by Wyatt et al. are ones typical of water where organic phosphate is important (Whitton et al., 2005). In particular, it would be of interest to know whether the factors with selective effects on the two algal assemblages are related to water movement or to chemistry. The influence of $D$. geminata growths on hyporheic hydraulic conditions in trout redds in the Clutha River catchment, New Zealand, was investigated by Bickel \& Closs (2008). Cover had no significant effects on flow into the substrate, hydraulic conductivity or hyporheic oxygen concentration, but there was a significant difference in the potential surface water-groundwater exchange between sites.

\section{Temperature and light}

The older records for central Europe mention it only from cold waters of the Alps (Krammer \& LangeBertalot, 1999), but records elsewhere include ones where the temperature probably exceeded $20^{\circ} \mathrm{C}$ at times, especially in shallow margins of lakes (e.g. Windermere, UK: Godward, 1937). Several of the lakes with $D$. geminata in Turkey reach $25^{\circ} \mathrm{C}$ in midsummer (e.g. Kolayli \& Şahin, 2007). In Norway, D. geminata grows in water ranging from 0 to $23^{\circ} \mathrm{C}$, but is more common and develops higher biomass in cool water that seldom exceeds $18^{\circ} \mathrm{C}$ in the vegetative period (Lindstrøm (2008). These authors also reported that it thrives in arctic regions characterized by a long period of darkness alternating with a period of constant daylight, such as Svalbard, and in regions with boreal light-dark alternation. There is general agreement that $D$. geminata is favoured by high light intensity and it seems probable that a combination of high light conditions and low temperature is especially important at the time of year when stalk formation is commencing.

Survival studies have been conducted on D. geminata taken from the Waitaki River, New Zealand, and kept in plastic containers under static conditions in the laboratory and subjected to various temperature and light regimes (Lagerstedt, 2007; Kilroy et al., 2007b; Kilroy, 2008); the river sometimes reaches at least $22^{\circ} \mathrm{C}$. At $28^{\circ} \mathrm{C}$, some cells survived 20-60 h and light had no effect on viability. About $70 \%$ cells were viable on day 60 at $5^{\circ} \mathrm{C}$. Survival could also occur for some weeks under cool 
conditions, if the cells were merely damp, rather than immersed in water.

Chemical factors

\section{General}

Information about the chemical environment largely relates to the water outside the colonies or mats and hence reflects the influence of the upstream catchment. Almost all accounts mention $\mathrm{pH}$ values in the range from just below neutral to well above $\mathrm{pH}$ 8.0. For instance, D. geminata has never been found in Norway in water $\mathrm{pH}<6.7$ (Lindstrøm, 2008). Spot measurements of $\mathrm{pH}$ and $\mathrm{O}_{2}$ made by various authors have indicated considerable diel changes in the presence of dense growths and more detailed studies were reported by Larned et al. (2007), where there was a marked effect in the Mararoa River, but less in the Oreti River. The pH ranged from 7.59 to 9.62 at one site in the former and dissolved $\mathrm{O}_{2}$ from 85 to $106 \%$.

Kawecka \& Sanecki (2003) reported two sites on R. Wisła with high salinity (451 and $183 \mathrm{mg} \mathrm{L}^{-1} \mathrm{Cl}$ : Table 2), but these seem to be the only records for such water. Lindstrøm (2008) reported that $>2.5 \mathrm{mg} \mathrm{L}^{-1} \mathrm{SO}_{4}$ is needed for $D$. geminata to proliferate.

\section{Calcium}

Various reports indicate the importance of sufficient $\mathrm{Ca}$ in the water, but the accounts from different countries suggest the lower limits may differ. D. geminata has never been found in Norway in water with $\mathrm{Ca}<1.8 \mathrm{mg} \mathrm{L}^{-1}$ (Lindstrøm, 2008). Lake Baikal, with several species, has $15.2 \mathrm{mg} \mathrm{L}^{-1} \mathrm{Ca}$ (Votintsev, 1961; Kozhova \& Izmest'eva, 1998). Twenty inflow rivers to the lake had values ranging from 7 to $24 \mathrm{mg} \mathrm{L}^{-1}$ (Votintsev et al., 1965). The mean value for the five streams and rivers in Poland and Slovakia with both $D$. tatrensis and D. geminata listed by Mrozińska et al. (2006a) was $45.2 \mathrm{mg} \mathrm{L}^{-1}$, a value similar to that for R. San (Kawecka \& Sanecki, 2003), but some streams draining the High Tatra Mts had considerably lower values (2.4$8.3 \mathrm{mg} \mathrm{L}^{-1} \mathrm{Ca}$ : Kawecka, in press a). Streams in northern England with $D$. geminata mostly drain catchments combining peaty soils and calcareous or other base-rich types of bedrock (Ellwood \& Whitton, 2007). Their water tends to be rich in humic materials when flow is high and with less humic materials, but harder, when flow is low. Any competitive advantage of a moderately hard water may be at least partly indirect. Among possible explanations are the influence of calcium in the catchment on nutrient release, its effect on another element important for D. geminata physiology or that it reduces the suitability of Didymosphenia for grazers.

\section{Phosphate}

Lindstrøm (2008) reported for Norway that D. geminata is pollution sensitive and tends to disappear when total $\mathrm{P}$ exceeds $20 \mu \mathrm{g} \mathrm{L}^{-1}$ and organic C exceeds $6.5 \mathrm{mg} \mathrm{L}^{-1} \mathrm{C}$. A survey (Løvstad, 2008) of rivers in the Oslo Region of Norway involving 100 samples in each of five TP classes found 23 records in the lowest $\left(0-12.5 \mu \mathrm{g} \mathrm{L}^{-1} \mathrm{P}\right), 5$ in the next highest $\left(12.5-25 \mu \mathrm{g} \mathrm{L}{ }^{-1} \mathrm{P}\right)$, but none in the others. The mean value for the five streams and rivers in Poland with D. tatrensis and D. geminata was $34 \mu \mathrm{g} \mathrm{L}^{-1} \mathrm{P}$ (Mrozińska et al., 2006a: unclear whether FRP or TP), while that for streams with D. geminata in northern Italy was $42 \mu \mathrm{g} \mathrm{L}^{-1} \mathrm{TP}$ (Beltrami et al., 2008c). Records for a number of inflow rivers were given by Tarasova \& Mescheryakova (1992) based on data for 1983 and 1984. The minimum average weighted concentrations of organic $\mathrm{P}$ among the various rivers surveyed were 5 and $7 \mu \mathrm{g} \mathrm{L}^{-1} \mathrm{P}$ and maximum values of 18 to $28 \mu \mathrm{g} \mathrm{L}^{-1}$ $\mathrm{P}$; both sets of values include rivers entering different parts of the lake. Detailed profiles for the water column (1987-1989) showed quite similar values for organic $\mathrm{P}$, ranging from 4 to $38 \mu \mathrm{g} \mathrm{L}{ }^{-1} \mathrm{P}$ near the surface and only slightly less with depth (Tarasova \& Mescheryakova 1992). However, neither the Baikal nor any other lake studies consider the possibility that organic $\mathrm{P}$ might be enriched in the microzone adjacent to the lake bottom in shallow water due to lateral drainage from shallow water; yet this seems a distinct possibility. All 12 sites on two New Zealand rivers reported by Larned et al. (2007) had low FRP (range 0.50$3.33 \mu \mathrm{g} \mathrm{L}^{-1} \mathrm{P}$ ) and, in all but one case, considerably more FOP (FRP:FOP range 0.097-1.11). (P fractions reported by authors as 'dissolved' rather than 'filtrable'; our estimates based on their table. All organic phosphate values quoted in this review are based on 
filtrable hydrolyzable phosphate and hence may include a polymeric inorganic phosphate component.)

The mean TP in Stony Gill based on monthly sampling over two years was considerably higher than that reported in other studies: $117 \mu \mathrm{g} \mathrm{L}^{-1} \mathrm{P}$ (Ellwood et al., 2008). As the abundance of D. geminata in this stream varies markedly from year to year, perhaps it survives here at the upper limits of its tolerance. However, mean FRP over the two-year period was $10 \mu \mathrm{g} \mathrm{L}^{-1} \mathrm{P}$, whilst during the period of abundant $D$. geminata growth, the mean value was $5.8 \mu \mathrm{g} \mathrm{L}^{-1} \mathrm{P}$. Most FRP is probably utilizable by $D$. geminata, but presumably not the particulate phosphate included in the 'total' fraction. FOP is the main source of $\mathrm{P}$ for $D$. geminata in Stony Gill (Ellwood \& Whitton, 2007), constituting 85\% of filtrable $\mathrm{P}$ on average and for several periods was almost the sole $\mathrm{P}$ fraction in the water. The absolute values for FOP and the FOP:FRP ratio were higher than in three other upland streams (Ellwood et al., 2008) lacking D. geminata.

\section{Nitrogen and N:P ratio}

Although use of the Redfield ratio N:P (16:1 molar, 7.2:1 by mass: Redfield et al., 1963) to indicate likely nutrient limitation based on water chemistry requires caution (Klausmeier et al., 2004), it provides a starting point for considering the ecology of D. geminata. The results for sites with sufficient data are summarized in Table 3. Based on a TIN:TP ratio of 31.7, Larson \& Carreiro (2008) concluded that Rapid Creek, South Dakota, was P-limited. TIN:TP was $31: 1$ by mass (based on means of $0.350 \mathrm{mg} \mathrm{L}^{-1}$ $\mathrm{N}$ and $0.11 \mathrm{mg} \mathrm{L}^{-1} \mathrm{P}$ ). Similarly, it seems likely that phototrophs in some other sites are also P-limited, such as the Brusago stream in north Italy (Beltrami et al., 2008c), since the N:P ratio was $21: 1$ based on mean and 31.7 based on median values. In the case of the two saline sites on R. Wisła, Poland, reported by Kawecka \& Sanecki (2003), the TIN:P ratio at the time of the spot measurements was very high, 29.1 and 125:1, though perhaps success here was also influenced by inocula from upstream. In contrast, bioassays of periphyton growth by Larned et al. (2007) on eight New Zealand sites (seven rivers) with D. geminata found significant enhancement by inorganic $\mathrm{P}$ at only three sites, but significant enhancements by $\mathrm{N} \times \mathrm{P}$ at two sites and $\mathrm{N}$ at two sites. If the water chemistry of these sites resembled the two quoted in Table 3, P limitation would not be expected. However, their experiment is complicated by the addition of inorganic phosphate, which would almost certainly inhibit phosphatase activities (Whitton et al., 2005), and so this would reduce the competitive advantage of $D$. geminata and perhaps even reduce $\mathrm{P}$ accumulation. Caution is needed in interpreting negative results with phosphatase assays as an indication of P saturation (Bowman, 2008) until it is known whether stalk phosphatase can be inhibited by phosphate, while the live cells are still responding to inorganic phosphate.

The literature on $\mathrm{N}$ and $D$. geminata deals almost entirely with inorganic sources, nitrate and sometimes also nitrite and ammonium-N. If organic phosphate is a major $\mathrm{P}$ source for $D$. geminata, the question arises where some organic $\mathrm{N}$ forms are also utilized. Although this may be unimportant where the aqueous inorganic N:TFP is very high, such as the study by Beltrami et al. (2008c), it is more plausible where the ratio is below the Redfield ratio, as sometimes occurs in Stony Gill (N-E England) and also in the New Zealand records in Table 3. The small streams draining into Harwood Beck, another N-E England stream with D. geminata (Whitton, 1984), are dominated near their source by the nitrogen-fixing cyanobacterium Rivularia and this process is particularly important in spring, when the ambient N:P ratio is least (Livingstone \& Whitton, 1984; Whitton et al., 1998). Didymosphenia geminata, which occurs slightly further downstream, starts to form colonies at about the same time, suggesting that it too would benefit if it had an ability to use $\mathrm{N}$ sources other than inorganic ions, but, in this case, part of the organic fraction.

\section{Substratum and other factors}

The use of tiles and Mylar strips (reflective plastic) as artificial substrates for growth of D. geminata was tested in two subalpine streams in the Rockies, USA (Vietti et al., 2007). The strips worked well in the spring period prior to the spring runoff, but no growth occurred either under high flow conditions in late spring and summer. The authors did not comment on the possible reasons for the difference. Apart from this, little has been reported about the influence of different substrata. The same applies to nutrient 
cycling within colonies, though Heuff \& Horkan (1984) speculated for R. Caragh, S-W Ireland, whether these and the epiphytic stalked diatoms inside them might accumulate silica(te) from the sand accumulated in the colonies rather than the water column, where silicate concentrations were quite low. Although this seems unlikely, it emphasizes the need for silicate measurements during the main growing season. The presence of loose or attached organisms inside the colonies may have a marked influence on the chemical environment there, sufficient, for instance, to lead to differences in dissolved gases between the inside of the colony and the external environment. A study (Larned et al., 2007) of dissolved oxygen with microelectrodes inside colonies in the Mararoa River, New Zealand, found peaks at the mat-water interface, but larger ones below the surface of most mats, and gradients of oxygen concentration from the pigmented surface to the subsurface peak. Larned et al. speculated that the peaks were due to metabolically active phototrophs inside the mats. Such differences in dissolved oxygen seem likely, but further studies including temperature measurements are needed, because the differences reported by Larned et al. were minor and expressed as percent saturation.

\section{Catchment}

It is important to consider the catchment as a whole when assessing factors influencing $D$. geminata. The catchment not only has an influence on the physical and chemical factors where mass growths occur, but may provide upstream sites maintaining populations able to inoculate downstream sites. Although many surveys have focussed on downstream growths, there are records much nearer the source, such as $1 \mathrm{~km}$ downstream in Beltrami et al. (2008c) and the small tributary of the R. Coquet mentioned above. It can even occur at the source, as reported by Gilbert et al. (2005) for calcareous springs entering Cowside Beck in the Malham area, UK. However, Kilroy (2008) stated that some spring-fed streams in New Zealand appear to be resistant to colonization and this has been incorporated in modelling its potential spread in New Zealand.

The importance of considering the upstream catchment was shown by Weilhofer et al. (2006) with a presence-absence study of 485 streams in western USA between 2000 and 2003 with respect to a range of environmental features. Regression tree analysis showed that the presence of tundra within the watershed was the major predictor for the presence of D. geminata. For sites without tundra, watershed disturbance was the major predictor. Streams and rivers elsewhere with abundant $D$. geminata also often have peaty soils in at least part of the catchment This is the situation at sites in northern England, including $\mathrm{R}$. Tees and several upland tributaries (Whitton, 1984), Coquet and Stony Gill (Ellwood \& Whitton, 2007) and R. Eden, Cumbria. Peat is also important in the catchment of the R. Glåma, Norway (Skulberg \& Lillehammer, 1984) and several rivers in southern Poland, e.g. R. Dunajec (Mrozińska-Broda \& Czerwik-Marcinkowska, 2004) and Czarna Orawa (Noga, 2003). It probably applies to many rivers with abundant growths on Vancouver Island, Canada (Bothwell, 2006), and South Island, New Zealand (Biggs et al., 2006).

We suggest that a key factor influencing growth of D. geminata in these catchments is the concentration of organic phosphate in the water. Detailed chemical analyses are available for only a few sites with D. geminata, but much of the phosphate in other streams draining peaty soils in northern England is organic, sometimes with a very high peak in late winter or spring and low concentrations for much of the rest of the year (Livingstone \& Whitton, 1984; Christmas \& Whitton, 1998a, b; Turner et al., 2001, 2003). Although this corresponds to the period of active motility of individual $D$. geminata cells and the early period of colony formation, the decrease in organic phosphate during summer in Stony Gill (with D. geminata) is less marked (Ellwood et al., 2007, 2008), permitting continued rapid growth.

It seems likely that large-scale environmental changes may have influenced nutrient release from peat, which may in turn have led to the increases in D. geminata growths. Rising temperature can lead to an increased rate of breakdown of peat, with loss of $\mathrm{CO}_{2}$ and release of organic compounds including organic phosphate to streams, with the effect being enhanced by atmospheric $\mathrm{N}$ deposition (Bragazza et al., 2006). Based on a comparison between regions in Europe with different levels of $\mathrm{N}$ deposition, these authors concluded that increased atmospheric $\mathrm{N}$ deposition led to enhanced microbial activity in the peat, as shown by phosphomonoesterase and 
$\beta$-glucosidase activities. As humic materials, such as fulvic and humic complexes, can antagonize phosphatase activity (Boavida \& Wetzel, 1998) competitively and non-competitively (Wetzel, 1992), any increase in stream water concentrations might be expected to reduce phosphomonoesterase activity. Has D. geminata evolved phosphatases to deal with this problem? The possibility that $D$. geminata can use inositol phosphates (McKelvie, 2007) and phytate (Greiner, 2007) should also be checked. If climatic warming and atmospheric $\mathrm{N}$ deposition have both favoured increases in D. geminata because of their influence on nutrient release, it will require detailed studies to assess their relative importance in particular catchments. We guess that warming has been more important for D. geminata at its more northern sites and atmospheric $\mathrm{N}$ in streams in central Europe.

Even if different catchments in one region have an extensive cover of peaty soil, local differences may be expected in flow and water chemistry, perhaps especially with respect to organic $\mathrm{N}$ and $\mathrm{P}$ components. Successful algae, such as Didymosphenia, will be ones that can adapt closely to conditions in a particular catchment, something which may be less important for downstream algae subject to nutrient inputs from domestic and agricultural sources. Perhaps some of the morphological variation within $D$. geminata is a response to different catchment characteristics.

\section{Biotic interactions}

Colonies include a range of other organisms attached to stalks or motile forms: those from R. Coquet in June 2006 and June 2007 included epiphytic bacteria, coccoid and filamentous non-heterocystous cyanobacteria, Amphora, small-celled Cymbella, Tabellaria, several naviculoid species, ciliates and other protozoa, and chironomids (Ellwood \& Whitton, 2007, and unpublished data). The copious production of stalk material can be considered analogous to the extracellular polysaccharide matrix production of biofilms. The biofilm matrix allows heterotrophic and autotrophic organisms to create various microenvironments, acts as a trap for soluble and particulate nutrients and a diffusion barrier that promotes retention of extracellular enzymes and hydrolysed substrates (Freeman \& Lock, 1995). Staining for phosphomonoesterase showed that some cyanobacteria and algae, but not all, had obvious activity, though this probably totalled much less than activity associated with the stalks (Ellwood \& Whitton, 2007). Achnanthidium minutissimum in particular has been a frequent stalk epiphyte at almost all D. geminata sites in the British Isles sampled in summer (unpublished data). A. minutissimum, Cymbella excisa, Gomphonema olivaceoides and Diatoma moniliformis occurred attached to or in close association with stalks of Didymosphenia geminata in the Flathead River, Montana (Wyatt et al., 2008). Epiphytic Hannaea arcus growing in colonies of Didymosphenia geminata in streams of the Swedish arctic released cells into the water (drift) around mid-day, except for winter when it occurred at other times of day (Round, 1984).

Several studies have reported changes in macroinvertebrate composition resulting from the change in habitat and, for grazers, the change in food material (Larned et al., 2006). In British Columbia, a salmon channel with conspicuous algal growths, especially Didymosphenia, showed reduced zoobenthos diversity compared with the main stream (Mundie \& Crabtree, 1997); the composition of salmonid food organisms changed on passing down the channel from 57\% to 93\% Chironomidae. Several authors have reported decreases in abundance of Ephemeroptera, Plecoptera and Trichoptera. These appeared to be replaced by smaller organisms, midges and aquatic worms in Rapid Creek, South Dakota (Larson, 2008), though one group of Ephemeroptera, the Baetidae, did increase (Larson, 2007). Larson found that the relative abundance of Oligochaeta and Hirudinae was positively correlated with \% cover of D. geminata, while one oligochaete, Nais sp., was the most dominant invertebrate at the site with the greatest $D$. geminata cover. A New Zealand study found a reduction in the same three orders ('EPT') and a shift to predominance of crustaceans, other insect orders and worms (Larned et al., 2007); in general there was an increase in invertebrate abundance and diversity. In apparent contrast to this, Pepin \& Hauer (2002) found no difference in mean EPT density between upwelling and downwelling sites on the Flathead River, Montana, although a study by Wyatt et al. (2008) reported that D. geminata was associated with downwelling sites in the same river (see above). However, Pepin and Hauer did find species-specific responses to differential hyporheic exchange, which were correlated with differences in algal biomass and vertical hydraulic gradient. 
Stable isotope analysis of components of two streams in the Sierra Nevada, USA, showed similar carbon signatures among periphyton, grazers and predators in the stream without $D$. geminata, but disparate signatures in the one with the diatom (Rost et al., 2008). The trout in the D. geminata stream were less dependent on algal carbon than those in the adjacent stream.

The Plecoptera and Trichoptera in particular may be expected to include taxa which can graze D. geminata cells or, in a few cases, the stalks (M. C. Lucas, pers. comm.). Studies on rivers where D. geminata has been abundant for a long time would indicate to what extent this has favoured species with this ability. In one such river, the Coquet in N-E England, late summer material of D. geminata consists largely of stalks, with only a few cells remaining attached to the stalks (unpublished data). However, the relative importance of grazing and flood damage in removing cells is unclear. Another factor to be considered is the possibility that $D$. geminata may include toxic components. The lower parts of stalks sometimes have frequent epiphytic cyanobacteria, a taxonomic group which are well known to form microcystins (Codd et al., 2005). However, Aboal et al. (2005) reported the presence of microcystins, especially microcystin LR, in the mucilaginous colonies of Cymbella affinis from the Alharabe R. in N-E Spain; the test samples did not include cyanobacteria, though cyanobacteria were frequent in the river and so the possibility of their microcystins being trapped in the Cymbella colonies could not be ruled out. Further studies (based on HPLC-mass spectrometry) have now indicated the presence of microcystins in two populations of D. geminata collected quite late in the growth season: Stony Gill (UK) in July 2000 and R. Puntledge (Vancouver Is) in September 2007 (M. Aboal, pers. comm.). In neither case were there conspicuous upstream growths of cyanobacteria nor did the stalks have frequent cyanobacterial epiphytes.

\section{Environmental management}

An organism to conserve

Didymosphenia geminata was quoted as an endangered species (category $1=$ almost extinct) in a German Red list of diatoms by Lange-Bertalot \&
Steindorf (1996). Whatever the earlier situation, it had in fact become quite widespread in southern Germany by then (see above). In the UK, although $D$. geminata was common for many years in several rivers draining the Cheviots in N-E England and S-E Scotland, it was included in submissions to the Secretary of State justifying two of these rivers, the Coquet (31 July 1996) and the Till (1 November 1999) being recognized as Sites of Special Scientific Interest, and thus imposing conservation requirements. The submission for R. Coquet stated that the diatom 'produces a seasonal bloom in streams on volcanic rocks; and the Cheviots are the only location in England where this phenomenon is recorded'. Whether this was strictly true at the time is unlikely, but in any case, there are other rivers now with conspicuous growths. However, its importance locally as an otherwise rare plant was emphasized again in Environment Agency (of England and Wales) information posted on the internet on 27 March 2006 (Rob Walsh: 'Rare species thrive in Northumberland').

An organism to worry about: increase and invasion

The literature reviewed above and many local records indicate that conspicuous growths of $D$. geminata have appeared in recent years in rivers where none had been reported previously. Major changes have occurred. How much these result from new invasion to a catchment or are a response to environmental changes is less clear. Citing Kawecka \& Sanecki (2003), Campbell (2008) states that D. geminata is native to the Ponto-Caspian bioregion, but the paper by the former authors includes no such comment. Campbell also states that it has been introduced to parts of Eurasia and the UK and quotes nine papers in support. However, none of these papers actually suggest this and the various fossil and 19th century records provide evidence that in some cases it is definitely not so. On the other hand, the study by Bhatt et al. (2008) of rivers in the Indian Himalayas suggests the possibility that spread may have been relatively recent there and linked to the introduction of brown trout to particular rivers. In $\mathrm{N}$. America, the situation seems quite similar to that in Europe, though recent occurrences in some western rivers, especially on Vancouver Island during the 1990s, consist of thicker mats and probably more extensive growths than anything seen in Europe. 
It is, however, the situation in New Zealand which has gained the most attention. All the reports state that it is an invader, a response to the sudden occurrence of huge nuisance growths, when there had only been one previous record of the species from the country and that considered erroneous (pers. comm. from C. Viegleis in Campbell, 2008). However, as discussed by Van de Vijver et al. (2008) for recent records in a European river of the diatom Psamnothidium abundans, a species previously considered to be a subantarctic endemic, few river systems in any country have been studied in enough detail to conclude that an alga is almost certainly absent at the time of study. Rather strangely, these authors quote as a fact (based on Spaulding et al. 2005) that Didymosphenia geminata has spread to New Zealand recently. Bothwell \& Spaulding (2008) use a slightly less emphatic wording than most previous authors: 'almost certainly the result of a species introduction'. Larned et al. (2007) state that 'Few of the affected rivers were sites of environmental monitoring prior to the $D$. geminata incursion, so baseline ecological conditions are not well-documented'. The New Zealand Parliamentary Library report mentions credible retrospective reports that it was visible in the Mararoa River as early as 2001. Even then it must surely have been overlooked for some years for populations to have increased to the 2004 level.

Whether or not D. geminata has been present for much longer or is even native, it seems likely that a new ecotype has contributed towards recent changes. Should a new ecotype have arrived from elsewhere, perhaps favoured by similar environmental changes in New Zealand and its original country, then other ecotypes may have spread between countries in recent years. Further spreads also seem likelyperhaps even from North America or New Zealand to Eurasia. The situation should become clearer when there are molecular studies involving at least two gene sequences in a large number of populations from many parts of the world combined with detailed studies within individual river catchments.

Nuisance problems

In spite of the conspicuous growths of D. geminata in many rivers of Europe, in most cases concern about them has been little more than members of the public wondering whether floating fragments of mat are sewage or the dirty white remnants of stalks at the end of summer are bacterial. However, large masses in the R. San, S-E Poland, in 1994 were sufficient to plug water filters, impeding the use of river water in supply systems (WIOŚ-Jaslo, 1996).

Questions have sometimes been raised about interference with sports fishing, but there seem to have been few problems in Europe. The R. Coquet in $\mathrm{N}-\mathrm{E}$ England, with its long record for D. geminata, was and still is well known for its migratory salmon (Salmo salar) and migratory trout ( $S$. trutta) (Alabaster, 1970; APEM, 2008). Although salmonid stocks in the Coquet have undoubtedly exhibited annual fluctuations and probably also some longer trends, stocks have consistently exceeded conservation limits set over the last decade. In a recent salmon action review, D. geminata was not mentioned as an issue of concern for salmon or trout stocks (APEM, 2008). Neither does there appear to have been any observation or concern about impacts of $D$. geminata on angling activities, although most angling in the Coquet occurs downstream of where D. geminata is abundant (M. C. Lucas, pers. comm). Some of the most productive Atlantic salmon rivers in Norway are also the ones with the most extensive D. geminata growths (Lindstrøm \& Skulberg, 2007, 2008). The situation in Iceland is similar: in spite of concern about $D$. geminata growths, they have had no obvious negative impacts on Salmo salar populations (Jónsson, 2008).

In North America, there have been more complaints, mostly relating to sports fishing, fouling lines, lures and flies, though occasionally also itchy eyes of swimmers downstream of large mats (Arkansas Department of Environment Quality, 2006), while Beeson \& Mitchum (2006) worry about loss of habitat features for fish reproduction, feeding and rearing. Complaints in some cases may have been as much as a response to change as to practical problems, but growths in Vancouver Island in the early 1990s caused real unease. However, assessment of records for chum (Oncorhynchus keta) and coho (O. kisutch) salmon escapement and productivity suggest that Didymosphenia geminata infestation on Vancouver rivers had either no detectable impact or, in some cases, a positive effect on productivity (Bothwell et al., 2008). Similarly, steelhead (O. mykiss) productivity was the same in rivers with and without D. geminata both before and during the 
period of mass growths. In contrast, a large decline in the abundance of adult brown trout in Rapid Creek, South Dakota, coincided with the start of D. geminata mass growths in 2002 (Shearer \& Erickson, 2006; Larson, 2008) and it was strongly suspected that the diatom was an important contributory factor. Youngof-year and age-1 fish were abundant, but the population became 'bottlenecked' at this stage.

It is the massive growths in some rivers of the South Island of New Zealand that have raised most attention, because of their possible impact on sports fishing and water sports such as kayaking. Vieglais (2008) stated that an economic impact assessment estimated the cost of the alga, in the absence of government intervention, to be $\$ 158$ million over the 8 years post discovery. However, a survey by Larned et al. (2007) of four New Zealand rivers including reaches with and without $D$. geminata found that the highest density of galaxid fish was at one of the Oreti River sites with moderate D. geminata growth. Few other differences between sites with and without D. geminata were detected.

If the report of microcystins in D. geminata (see above) proves to be a widespread phenomenon, then these and future studies on fish need to evaluated more carefully in case there are situations where microcystins accumulate in fish to concentrations potentially harmful for human consumption.

\section{Control}

Following the attention caused in 2004 by the massive growths in the lower Waiau and Mararoa Rivers, D. geminata was labelled an undesirable alien species by Biosecurity New Zealand (New Zealand Parliamentary Library, 2006; Vieglais, 2008). Staff responsible for water management and Biosecurity rapidly organized measures aimed at containment, control or eradication (Kilroy, 2007a). Much effort was put into reducing the risk of inoculation to further rivers. This included studies on the factors influencing survival of cells accidentally removed from the river. It seems likely, however, that this will merely slow the rate at which the species spreads between rivers, rather than a more permanent solution. Ten potential algaecides were investigated (Jellyman et al., 2006) and further trials showed that a chelated copper compound was the most effective in killing $D$. geminata cells and minimizing effects on other organisms (Clearwater et al., 2007a, b; Mississippi Interstate Cooperative Resource Association, 2008).

The processes involved in cell mortality were not investigated in the New Zealand project, but Durrieu et al. (2003) showed that all the heavy metals tested (Cr, Ni, Cu, Zn, Cd, Hg, Pb) were highly inhibitory to Chlorella vulgaris surface phosphomonoesterase activity, and so perhaps the response in the New Zealand study was at least partly due to the influence on Didymosphenia geminata phosphatase activities. However, $\mathrm{Cu}$ is likely to be toxic to a wide range of organisms in the river, and so the approach seems risky. In addition, upland streams with elevated $\mathrm{Zn}$ and $\mathrm{Cu}$ are often dominated by metal-tolerant strains of other organic phosphate-utilizing algae (Whitton et al., 2005), and so D. geminata might also evolve strains tolerant to these and perhaps the other metals. The fact that it was recorded (Szabó et al., 2005) in R. Tisza, Hungary, a year after the river had been subjected to major contamination by heavy metals, with copper the most important, indicates that control with a copper algaecide is likely to be short-lived. D. geminata was also reported from the heavy metalpolluted Rudnaya River in eastern Russia (Barinova et al., 2008), with some enrichment by $\mathrm{Cu}$, though mainly $\mathrm{Zn}, \mathrm{Cd}$ and $\mathrm{Pb}$.

Understanding of the nutrient regime influencing D. geminata suggests a different approach-enhancing the growth of competitors, while ensuring that overall disturbance to the ecosystem is kept to a minimum. Larson (2008) describe a project initiated in Rapid Creek, S. Dakota, in May 2007. This involves adding slow release granular fertilizer to attain nutrient ratios near the Redfield ratio (see above). Their account does not give separate values for FRP and FOP, but Whitton \& Ellwood (2008), who also recommend adding inorganic phosphate to the river, state that the aim should be to enhance the ratio of inorganic to organic $\mathrm{P}$. Although the approach is essentially the same as that of Larson and Carreiro, it is important to establish which of the ratios, N:P or FRP:FOP, is more important, because this influences the amount of additional inorganic phosphate required and the season at which it is most likely to be effective, and also whether it is worth trying to reduce the $\mathrm{N}$ input.

If the FRP:FOP ratio is the one with most adverse effect on the competitive success of $D$. geminata, then 
it is important to reduce changes likely to enhance organic phosphate in the water, such as deforestation and soil disturbance. If the approach of adding inorganic phosphate to the water is adopted, it should be done in early spring when $D$. geminata is just starting to form stalks. Once the colonies have started, it is probably too late to achieve much success in that particular year (Whitton, 2008). It might be necessary to continue phosphate addition for several months each year. The site chosen for phosphate addition should be towards the upper end of the distribution range within the river, though it may be impractical to include small tributaries. If all the rivers in New Zealand have TP concentrations as low as the range (3.0-11.9 $\mu \mathrm{g} \mathrm{L}^{-1} \mathrm{P}$ ) reported by Larned et al. (2007), this approach to controlling nuisance growths seems entirely plausible. Enhancement by $10 \mu \mathrm{g} \mathrm{L}^{-1} \mathrm{P}$ in a river with $10 \mathrm{~m}^{3} \mathrm{~s}^{-1}$ flow needs $0.86 \mathrm{t} \mathrm{P}$ per day. A cheaper approach would be to manage any upstream sewage or other waste treatment operation such that only inorganic phosphate is released. It is more difficult to predict the likely impact of reducing inputs of combined nitrogen such that the N:P ratio in the river water is reduced, because of the uncertainty of its effect on the competitive success of $D$. geminata versus other algae.

The possibility of using immobilized phosphatase enzymes on substrata fixed in the river should also be tested. This would require finding robust enzymes that survive for long enough in the river to be feasible economically. This approach cannot be used together with slow-release $\mathrm{P}$ granules, because of phosphatase inhibition by Pi (Quiquampoix \& Mousain, 2005; Whitton et al., 2005). It might also be worthwhile flushing large growths from spillways or other structures immediately downstream of dams, though an experimental study of scouring in the East River, Colorado, found that recovery was rapid (Lee et al., 2008).

\section{Discussion}

The main environmental factors favouring Didymosphenia geminata seem clear. Kilroy et al. (2008) selected temperature, hydrological and substrate suitability, light availability and $\mathrm{pH}$ as factors to assess the likelihood of D. geminata growths developing in New Zealand rivers. The literature reviewed here confirms these, with high light conditions and, in the case of flowing waters, the annual flow regime, being especially important. However, many other algae have quite similar requirements and it is probably nutrient chemistry that is most important in the competitive success of $D$. geminata. Most, but not all, studies show that $D$. geminata thrives in waters where $\mathrm{N}: \mathrm{P}$ is high for much of the time; where more detailed information is available, such as Lake Baikal and upland streams in northern England, organic phosphate is an important and probably the main $\mathrm{P}$ source. What matters is the availability of organic phosphate under conditions where $\mathrm{Pi}$ is insufficient to avoid $\mathrm{P}$ limitation. The limited environmental data for other Didymosphenia species suggests that the requirement for high $\mathrm{pH}$ and the importance of organic phosphate are likely to be shared by them, but there are insufficient data to comment on the factors likely to give a selective advantage to particular species. Similarly, if Gomphonema and Cymbella prove to have broadly similar requirements, it remains to be shown how Didymosphenia competes with them. Is it merely the large, persistent stalks or are there other special features, such as differences in the ways these organisms utilize organic phosphate?

Many early studies of sites with $D$. geminata indicate that TP concentration was probably low or moderate, but it seems possible that the species sometimes occurs now at higher total concentrations than in the past. More detail about $\mathrm{N}$ and $\mathrm{P}$ fractions in the water is needed to assess whether this reflects a change in nutrient requirements. Unfortunately, most surveys omit FOP, including many related to the European Union Water Framework Directive (e.g. Kelly-Quinn et al., 2006). However, D. geminata is often associated with, or just downstream of, other algae occurring in water where FOP:FRP is high and/ or the phototrophs are known to show high surface phosphatase activities, such as Homoeothrix crustacea, Tolypothrix distorta var. penicillata, colonial Cymbella, Draparnaldia and Hydrurus foetidus (Gibson \& Whitton, 1987a, b; Whitton et al., 2005). Possible exceptions are sites where the upstream population is so high that it provides a large enough inoculum to colonize downstream sites less favourable for competitive success of $D$. geminata.

Assessing the importance of the various physical and chemical factors known to favour Didymosphenia 
requires understanding of how they provide a competitive advantage for Didymosphenia. Although many non-stalked diatoms can probably also utilize organic phosphate, Didymosphenia may be expected to do this more effectively as stalk development commences, because of the increased surface area. Periods combining low temperature and high light in spring probably favour D. geminata. Studies are needed to establish whether D. geminata mats maintain their competitive success against non-stalked diatoms later in the season, if the predominant $\mathrm{P}$ source shifts from organic to inorganic. This might occur, for instance, due to increased waste effluents in summer tourist areas, but also if stream biota release phosphatases (Whitton et al., 2005). It would be disadvantageous for D. geminata to release phosphatases to the water because this would increase ambient inorganic $\mathrm{P}$, and so it is important to establish whether phosphatase concentrations are low outside the stalks. Staining on the walls of $D$. geminata cells at times when the stalks show strong staining (Ellwood \& Whitton, 2007) suggests there may be an advantage for the cell to separate the main site of organic phosphate hydrolysis from uptake of inorganic phosphate. The diatom stalk has some similarity with the colourless multicellular 'hairs' in cyanobacteria and filamentous eukaryotic algae. Here, surface phosphatase activity, which increases when the organism becomes slightly P-limited, is largely or, in some cyanobacteria, entirely restricted to the hairs (Whitton et al., 2005).

It is more difficult to consider how D. geminata competes with other stalked diatoms, at least some of which also have phosphatase activity in or on their stalks (see above). Part of the reason may simply be outcompeting other stalked diatoms due to the stalks reaching further into the water. The larger stalks provide a more substantial structure for repeat branchings, leading to a thicker mat. However, it seems likely that differences in strategy for $\mathrm{P}$ acquisition are important. In the case of Cymbella, some colonial species have their stalks embedded in mucilage or even form hemispherical colonies, and so possibly they resemble those colonial cyanobacteria with hairs where the mucilage shows phosphomonoesterase, though not phosphodiesterase, activity and some enzyme usually passes into solution (Whitton et al., 2005).

It was suggested that changes in peat due to environmental changes may have led to increased nutrient release, especially organic phosphate, in upland streams and rivers and that this in turn may have favoured increases in D. geminata. There is evidence that Cladophora glomerata has also increased in some upland sites in the UK without obvious changes in human influence, such as the most upstream stretch of R. Wear (Whitton et al., 1998) and tributaries of R. Coquet (B. A. Whitton, unpublished data). Although increased phosphate is the most likely explanation, the possibility that changes in the peat have influenced vitamin release also needs to be studied, because $C$. glomerata requires thiamine and vitamin $\mathrm{B}_{12}$ (Moore \& McLarty, 1975; Hoffmann, 1990). The latter in particular plays a role in the succession of some marine diatoms (Swift, 1980), but awaits study in freshwaters.

As suggested by several authors, the changes in D. geminata populations reported for many rivers may involve new ecotypes. These may have evolved in response to the nutrient changes discussed here, which may in turn be due to large-scale environmental changes. If so, the different ecotypes may be expected to show obvious differences not only in stalk morphology, but also in the phosphatase activities associated with it, such as changes in enzyme kinetics and perhaps even the ability to utilize different types of organic phosphate molecule. If colony formation involves cell aggregation, this would also be favoured as stream populations increase. Any factor favouring a denser population would permit colony formation to start slightly earlier in the season.

Finally, we emphasize what an excellent organism Didymosphenia is for ecological studies. It is often recognizable macroscopically and visual checks are needed as well as routine sampling to establish its status at a site. It is almost always possible to distinguish from other diatoms by light microscopy without cleaning the frustule, though the latter is needed for reliable recognition to the species. Its large size aids study of topics like seasonal changes in morphology, how stalks form, stalk epiphytes and grazing. Perhaps, some of the severe nuisance problems will decrease naturally, as appears to have happened on Vancouver Island (Bothwell, 2006) and Iceland (Jónsson, 2008). Better understanding of the organism's ecology should permit control measures suitable for river management without the worries about spread between sites that currently occupy staff in New Zealand and parts of North America. 
Acknowledgements The authors are most grateful to those who have discussed this alga with us, especially Dr David Jewson (University of Ulster, UK) and Prof. Andrea Kirkwood (University of Ontario Institute of Technology, Canada). Dr Atko Heinsalu (Institute of Geology, Estonia) generously provided data on sediment records. Dr L. Ector (Department Environment et Agro-Biotechnologies, Centre de Recherche Public, Luxemburg) and Dr S. Blanco (Universidad de León, Spain) gave information on several references important for the map showing locations. Among the many others who helped with information or in other ways are N. Abdelahad (La Sapienza Università di Roma, Italy), M. Aboal (Universidad Murcia, Spain), I. Atazadeh (East Azerbaijan Agriculture and Natural Resources Research Center, Tabriz, Iran), M. E. Beltrami (IASMA Research Center, Natural Resources Department, Italy), M. L. Bothwell (National Water Research Institute, Nanaimo, Vancover Is., British Columbia, Canada), S. R. Chipps (South Dakota University, USA), T. J. Entwisle (Botanic Gardens Trust, Sydney, Australia), Liba Granina (Limnological Institute, Russian Academy of Sciences), B. J. Hicks, University of Waikato, New Zealand, M. G. Kelly (Bowburn Consultancy, UK), C. Kilroy (NIWA, New Zealand), S. Komulaynen (Karelian Research Centre, Russia), J. Kwandrans (Institute of Nature Conservation, Kraków, Poland), A. M. Larson (South Dakota Department of Environment and Natural Resources, USA), M. C. Lucas (Durham University, UK), D. G. Mann (Royal Botanic Garden, Edinburgh, UK), T. V. Nikulina (Institute of Biology and Soil Science, Vladivostok, Russia), J. Padisak (University of Veszprém, Hungary), A. Pentecost (Freshwater Biological Association, Windermere, UK), K. Piirsoo (Institute of Agricultural and Environmental Sciences, Estonia), S. A. Spaulding (US Geological Survey), A. Tuji (National Museum of Nature and Science, Tsukuba, Japan), H. van Dam (Consultancy for Water and Nature, The Netherlands), J. D. Wehr (Louis Calder Conservation and Ecology Center, Fordham University, USA) and D. G. Williams (Natural History Museum, London, UK).

\section{References}

Aboal, M., M. A. Puig \& A. D. Asencio, 2005. Production of microcystins in calcareous streams. The Alharabe River, Segura River basin of south-east Spain. Journal of Applied Phycology 17: 231-243.

Ács, E., K. Szabó, K. T. Kiss \& F. Hindák, 2003. Benthic algal investigations in the Danube river and some of its main tributaries from Germany to Hungary. Biologia, Bratislava 58: 545-554.

Alabaster, J., 1970. River flow and upstream movement and catch of migratory salmonids. J. Fish Biology 2: 1-13.

Antoine, S. E. \& K. Benson-Evans, 1983. Polymorphism and size variation in Didymosphenia geminata from Great Britain (Abstract). British Phycological Journal 18: 199200.

Antoine, S. E. \& K. Benson-Evans, 1986. Teratological variations in the River Wye diatom flora, Wales, U.K. In Ricard, M. (ed.), Proceedings Eighth International Diatom Symposium. Koeltz, Koenigstein: 375-384.
APEM, 2008. River Coquet. Salmon Action Plan Review. Report for Environment Agency (of England \& Wales) at Newcastle-upon-Tyne, July 2008. APEM Scientific Report 410230: 48 pp.

Arkansas Department of Environmental Quality, April, 2006. Didymosphenia geminata Didymo algae [available on internet at http://www.adeq.state.ar.us].

ASCONIT, 2007. Étude du peuplement diatomique de stations du RNB, du RCB et de la DCE dans la Région ProvenceAlpes-Côte d'azur. Campagne 2006. Rapport final-DIREN Alpes Provence Côte d'Azur, Le Tholonet, France.

Asprey, J. F., K. Benson-Evans \& J. E. Furet, 1964. A contribution to the study of South American freshwater phytoplankton. Gayana Botanica 10: 1-18.

Barinova, S., L. Medvedeva \& E. Nevo, 2008. Regional influences on algal biodiversity in two polluted rivers of Eurasia (Rudnaya River, Russia, and Qishon River, Israel) by bioindication and canonical correspondence analysis. Applied Ecology and Environmental Research 6(4): 29-59.

Beeson, D. R. \& K. Mitchum, 2006. The past and present status of Didymosphenia geminata in the upper East Boulder River. In Spaulding, S., R. Wiltshire \& L. Elwell (conference organizers), Current Knowledge of Didymosphenia geminata: Developing a Research and Management Response. Federation of Fly Fishers and EPA Region 8, held in association with Western Division American Fisheries Society Annual Meeting, May 15-16, 2006, Montana State University, Montana, USA: 29 pp, p. 8.

Beltrami, M. E., C. Cappelletti \& F. Ciutti, 2007. A first characterization of diatom communities from Trentino streams (Northern Italy). In Kusber, W.-H. \& R. Jahn (eds), Proceedings 1st Central European Diatom Meeting, 2007. Botanic Garden and Botanical Museum BerlinDahlem, Berlin: 6-10.

Beltrami, M. E., C. Cappelletti \& F. Ciutti, 2008a. Didymosphenia geminata (Lyngbye) M. Schmidt (Bacillariophyta) in the Danube basin: New data from the Drava river (northern Italy). Plant Biosystems 142: 126-129.

Beltrami, M. E., C. Cappelletti, F. Ciutti, L. Hoffmann \& L. Ector, 2008b. Distribution and ecology of Didymosphenia geminata (Lyngbye) M. Schmidt (Bacillariophyta) in Trentino watercourses (Northern Italy). Cryptogamie Algologie 29: 141-160.

Beltrami, M. E., C. Cappelletti, F. Ciutti, L. Hoffmann \& L. Ector, 2008c. The diatom Didymosphenia geminata: distribution and mass occurrence in the Province of Trento (Northern Italy). Verhandlungen Internationale Vereinigung Limnologie 30: 593-597.

Berrendero, E., E. Perona \& P. Mateo, 2008. Genetic and morphological characterization of Rivularia and Calothrix (Nostocales, Cyanobacteria) from running water. International Journal of Evolutionary Microbiology 58: $447-460$.

Bhatt, J. P., A. Bhaskar \& M. K. Pandit, 2008. Biology, distribution and ecology of Didymosphenia geminata (Lyngbye) Schmidt an abundant diatom from the Indian Himalayan rivers. Aquatic Ecology 42: 347-353.

Bickel, T. O. \& G. P. Closs, 2008. Impact of Didymosphenia geminata on hyporheic conditions in trout redds: reason for concern? Marine and Freshwater Research 59: 1028-1033. 
Biggs, B. J. F., C. Kilroy \& C. C. Vieglais, 2006. A New Zealand science response to help manage Didymosphenia geminata - an unwanted diatom invader of freshwaters. In Spaulding, S., R. Wiltshire \& L. Elwell (conference organizers) Current Knowledge of Didymosphenia geminata: Developing a Research and Management Response. Federation of Fly Fishers and EPA Region 8, held in association with Western Division American Fisheries Society Annual Meeting, May 15-16, 2006, Montana State University, Montana, USA: 29 pp, p. 7.

Blanco, S. \& L. Ector, 2008. Didymosphenia geminata (Bacillariophyta, Gomphonemataceae) una amenaza para nuestros rios. Cuadernos de Biodiversidad 28: 3-6 (in Spanish).

Boavida, M. J. \& R. G. Wetzel, 1998. Inhibition of phosphatase activity by dissolved humic substances and hydrolytic reactivation by natural ultraviolet light. Freshwater Biology 40: 285-293.

Bonardi, E., 1888. Premières recherches sur les diatomées de Vall'Intelvi. Journal de Micrographie 12: 303-382.

Bothwell, M. L. \& S. A. Spaulding, 2008. Synopsis. The 2007 International Workshop on Didymosphenia geminata. In Bothwell, M. L. \& S. A. Spaulding (eds), Proceedings of the 2007 International Workshop on Didymosphenia geminata. Canadian Technical Report on Fisheries and Aquatic Sciences 2795: xiii-xxi.

Bothwell, M. L., D. M. J. Sherbot, J. Denisgeger, H. Wright, D. Lynch \& D. J. Kelly, 2006. Blooms of Didymosphenia geminata in rivers of Vancouver Island. 1990 to present: A sign of environmental change or a new invasive species? In Spaulding, S., R. Wiltshire \& L. Elwell (conference organizers), Current Knowledge of Didymosphenia geminata: Developing a Research and Management Response. Federation of Fly Fishers and EPA Region 8, held in association with Western Division American Fisheries Society Annual Meeting, May 15-16, 2006, Montana State University, Montana, USA: 29 pp, p. 9.

Bothwell, M. L., B. Holtby, D. R. Lynch, H. Wright \& K. Pellett, 2008. Did blooms of Didymosphenia geminata affect runs of anadromous salmonids on Vancouver Island? In Bothwell, M. L. \& S. A. Spaulding (eds), Proceedings of the 2007 International Workshop on Didymosphenia geminata. Canadian Technical Report on Fisheries and Aquatic Sciences 2795: 50-53.

Bowman, M. F., 2008. Increased Didymosphenia geminata biomass in response to low-level phosphorus enrichment of oligotrophic rivers. In Bothwell, M. L. \& S. A. Spaulding (eds), Proceedings of the 2007 International Workshop on Didymosphenia geminata. Canadian Technical Report on Fisheries and Aquatic Sciences 2795: 30-34.

Bowman, M. F., P. A. Chambers \& D. W. Schindler, 2005. Epilithic abundance in relation to anthropogenic changes in phosphorus bioavailability and limitation in mountain rivers. Canadian Journal of Fisheries and Aquatic Sciences 62: 174-184.

Bragazza, L., C. Freeman, T. Jones, H. Rydin, J. Limoens, N. Fenner, T. Ellis, R. Gerdol, M. Hájek, T. Hájek, P. Iacumin, L. Kutnar, T. Tahvanainen \& H. Toberman, 2006. Atmospheric nitrogen deposition promotes carbon loss from peat bogs. Proceedings of National Academy of Sciences 103(51): 19386-19389.
Brun, J., 1880. Diatomées des Alpes et du Jura et de la région suisse et française des environments de Genève. Masson, Genève et Paris: 146 pp. +9 plates; also 1965 facsimile (in French).

Cadjo, S. A., A. Miletic \& A. Djurkovic, 2005. Phytoplankton, physico-chemical and saprobiological characteristics of the Danube River, on the stretch through Serbia. Republic Hydrometeorological Service of Serbia, Belgrade: 13.

Campbell, M. L., 2008. Organism impact assessment: risk analysis for post-incursion management. International Council for the Exploration of the Sea 65: 795-804.

Canter-Lund, H. \& J. W. G. Lund, 1995. Freshwater Algae. Their Microscopic World Explored. Biopress, Bristol, UK: 360 pp.

Carter, C. C., 2007. Didymosphenia geminata (Lyngbye) M. Schmidt in a non-typical environment. Quekett Journal of Microscopy 49:431-432 (Author is C. F. Carter: cited incorrectly in journal).

Carter, J. R., 1960. Diatom notes. British freshwater forms of the genus Gomphonema. Journal of the Quekett Microscopical Club 12: 255-265.

Cary, S. C., B. J. Hicks, K. J. Coyne, A. Rueckert, C. E. C. Gemmill, C. M. E. Barnett, 2007. A sensitive genetic based detection capability for Didymosphenia geminata (Lyngbye) M. Schmidt: Final report. Client report prepared for MAF Biosecurity New Zealand. CBER Contract Report No. 62. Centre for Biodiversity and Ecology Research, Department of Biological Sciences, School of Science and Engineering, The University of Waikato, Hamilton, New Zealand.

Cary, S. C., B. J. Hicks, C. E. C. Gemmill, A. Rueckert \& K. J. Coyne, 2008 A sensitive genetic-based detection and enumeration method for Didymosphenia geminata. In Bothwell, M. L. \& S. A. Spaulding (eds), Proceedings of the 2007 International Workshop on Didymosphenia geminata. Canadian Technical Report on Fisheries and Aquatic Sciences 2795: 6-9.

Cassie, V., 1984. Checklist of the freshwater diatoms of New Zealand. Bibliotheca Diatomologica 4: 5-129.

Cazaubon, A., 1988. Etude des peuplements d'algues en dérive et benthiques (épiphytiques, épilithiques, épipsammiques et épipéliques) des rivières méditerranéennes (sud-est de la France: Provence et Corse). Ph. D. Thesis, Faculté des Sciences de Saint-Jérome, Université de Droit, d'Economie et des Sciences d'Aix-Marseille III, Marseille, France.

Chapman, V. J., R. H. Thompson, \& E. C. M. Segar, 1957. Check list of the fresh-water algae of New Zealand. Trans R Soc N Z 84(4): 695-747.

Cholnoky, B. J., 1924. Bacillarieák coloniának ismereténez. Folia Cryptogamica 1: 3-24.

Christmas, M. \& B. A. Whitton, 1998a. Phosphorus and aquatic bryophytes in the Swale-Ouse river system, north-east England. 1. Relationship between ambient phosphorus, internal $\mathrm{N}: \mathrm{P}$ ratio and surface phosphatase activity. Science of the Total Environment 210/211: 389-399.

Christmas, M. \& B. A. Whitton, 1998b. Phosphorus and aquatic bryophytes in the Swale-Ouse river system, north-east England. 2. Phosphomonoesterase and phosphodiesterase activities of Fontinalis antipyretica. Science of the Total Environment 210/211: 401-409. 
Clearwater, S. J., P. G. Jellyman, B. J. F. Biggs, C. W. Hickey, N. Blair \& J. S. Clayton, 2007a. Didymosphenia geminata experimental control trials. Stage Two Phase Two (testing the effectiveness of Gemex ${ }^{\mathrm{TM}}$, a chelated copper formulation). NIWA Report HAM2006-174.

Clearwater, S. J., P. G. Jellyman, B. J. F. Biggs, C. W. Hickey, N. Blair \& J. S. Clayton, 2007b. Didymosphenia geminata experimental control trials. Stage Three Phase One (assessment of the effectiveness of Gemex ${ }^{\mathrm{TM}}$, a chelated copper formulation, in a small river). NIWA Report HAM2007-060.

Clemens, W. A., D. S. Rawson \& J. L. McHugh, 1939. A biological survey of Okanaga Lake, British Columbia. Bulletin Fisheries Research Board of Canada 56: 1-70.

Codd, G. A., J. Lindsay, F. M. Young, L. F. Morrison \& J. S. Metcalf, 2005, Harmful cyanobacteria. In Huisman, J., C. P. Matthijs \& P. M. Visser (eds), Harmful Cyanobacteria. Springer, Dordrecht: 241 pp, pp. 1-23.

Columbia River Integrated Environmental Program, 2005. Public update on the environmental health of the Columbia River from Hugh Keenleyside Dam to the border. Library and Archives Canada Cataloguing ISBN 0-7726-5411-5, $12 \mathrm{pp}$.

Comère, J., 1894. Les Diatomées des Pyrénées. Bulletin Societé Ramond 1(5): 16-75.

Coyne, K. J., T. D. Niederberger, B. J. Hicks \& S. C. Cary, 2006. Detection of invasive algae using DNA probes. In Spaulding, S., R. Wiltshire \& L. Elwell (conference organizers) Current Knowledge of Didymosphenia geminata: Developing a Research and Management Response. Federation of Fly Fishers and EPA Region 8, held in association with Western Division American Fisheries Society Annual Meeting, May 15-16, 2006, Montana State University, Montana, USA. 29 pp, p.10.

Dawson, P. A., 1973a. The morphology of the siliceous components of Didymosphaenia geminata (Lyngb.) M. Schm. British Phycological Journal 8: 65-78.

Dawson, P. A., 1973b. Further observations on the genus Didymosphaenia M. Schmidt-D. siberica (Grun.) M. Schm. British Phycological Journal 8: 197-201.

Day, S. A., R. P. Wickham, T. J. Entwisle \& P. A. Tyler, 1995. Bibliographic check-list of non-marine algae in Australia. Flora of Australia Supplementary Series 4: vii + 276.

Dorogostaisky V., 1904. Materiaux pour servir à l'algologie du lac Baikal et de son bassin. Bulletin de la Societé Impériale des Naturalistes du Moscou, n.s. 18: 229-265 (also quoted as 2: 229-265).

Durrieu, C., I. Badreddine \& C. Daix, 2003. A dialysis system with phytoplankton for monitoring chemical pollution in freshwater ecosystems by alkaline phosphatase assay. Journal of Applied Phycology 15: 289-295.

Duthie, H. C. \& R. Socha, 1976. A checklist of the freshwater algae of Ontario, exclusive of the Great Lakes. Le Naturaliste Canadien 103: 89-109.

Eichman, J. K., C. Holderman \& G. T. Lester, 2006. Didymosphenia geminata and the periphyton community of the Kootenai River, Montana and Idaho. In Spaulding, S., R. Wiltshire \& L. Elwell (conference organizers), Current Knowledge of Didymosphenia geminata: Developing a Research and Management Response. Federation of Fly Fishers and EPA Region 8, held in association with
Western Division American Fisheries Society Annual Meeting, May 15-16, 2006, Montana State University, Montana, USA: 29 pp, p. 11.

Ellwood, N. T. W. \& B. A. Whitton, 2007. Importance of organic phosphate hydrolyzed in stalks of the lotic diatom Didymosphenia geminata and the possible impact of climate change. Hydrobiologia 592: 121-133.

Ellwood, N. T. W., S. M. Haile \& B. A. Whitton, 2008. Aquatic plant nutrients, moss phosphatase activities and tissue composition in four upland streams in northern England. Journal of Hydrology 350: 246-260.

Ennis, G. L., 1974. Unpublished data, quoted by Stein \& Borden (1979).

Ennis, G. L., 1975. Unpublished data, quoted by Stein \& Borden (1979).

Erickson, J. W. \& J. S. Shearer, 2006. Appearance of Didymosphenia geminata in the Black Hills of South Dakota. In Western South Dakota Hydrology Conference, April 18, 2006, Rapid City, South Dakota: 37 pp, p. 10 (sd.water.usgs.gov/WSDconf/2006conference).

Falasco, E., F. Bona, G. Badino, L. Hoffmann \& L. Ector, 2009. Diatom teratological forms and environmental alterations: a review. Hydrobiologia 623: 1-35.

Feyzioğlu, A. M. \& K. Seyhan, 2007. Phytoplankton composition of south east Black Sea coast. J. Black Sea/Mediterranean Environment 13: 61-71.

Flower, R. J., 2005. A review of diversification trends in diatom research with special reference to taxonomy and environmental applications using examples from Lake Baikal and elsewhere. Proceedings of the Californian Academy of Sciences 56: 107-128.

Flower, R., G. Pomazkina, E. Rodionova \& D. E. Williams, 2004. Local and meso-scale diversity patterns of benthic diatoms in Lake Baikal. In Poulin, M. (ed.), 17th International Diatom Symposium 2002, Ottawa, Canada. Biopress, Bristol: 69-92.

Foged, N., 1981. Diatoms in Alaska. Bibliotheca Phycologica, Vol. 53. J. Cramer, Germany: 317 pp.

Foged, N., 1993. Some diatoms from Siberia especially from Lake Baikal. Diatom Research 8: 231-279.

Fraser, S. P. C., 1966. The seasonal growth and distribution of algae in the Grand River. M. Sc. Thesis, University of Waterloo, Canada, 137 pp.

Freeman, C. \& M. A. Lock, 1995. The biofilm polysaccharide matrix: a buffer against changing organic substrate supply. Limnology \& Oceanography 40: 273-278.

Gágyorová, K. \& P. Marvan, 2002a. Abstract. Czech Phycology (Bulletin of the Czech Phycological Society) 2: 2 .

Gágyorová, K. \& P. Marvan, 2002b. Didymosphenia geminata a Gomphonema ventricosum (Bacillariophyceae) v Moraskovleských. Didymosphenia geminata and Gomphonema ventricosum (Bacillariophyceae) in Moraskovleské Beskyda Mts. Czech Phycology; Oluymouc 2: 61-68 (in Czech, with English Abstract).

Geitler, L., 1932. Der Formwechsel der pennaten Diatomeen (Kieselalgen). Archiv für Protistenkunde 78: 1-226.

Giaj-Levra, P. \& O. Abate, 1994. Le diatomée d'acqua dolce in Italia. ENEA Serie Studi Ambientali, Rome: 290pp.

Gibson, M. T. \& B. A. Whitton, 1987a. Hairs, phosphatase activity and environmental chemistry in Stigeoclonium, 
Chaetophora and Draparnaldia (Chaetophorales). British Phycological Journal 22: 11-22.

Gibson, M. T. \& B. A. Whitton, 1987b. Influence of phosphorus on morphology and physiology of freshwater Chaetophora, Draparnaldia and Stigeoclonium (Chaetophorales, Chlorophyta). Phycologia 26: 59-69.

Gilbert, O., H. Goldie, D. Hodgson, M. Marker, A. Pentecost, M. Proctor \& D. Richardson, 2005. The ecology of Cowside Back, a tributary of the River Skirfare in the Malham area of Yorkshire. Field Studies Council, Malham Tarn Field Centre, Settle, North Yorkshire BD24 9PU, UK: 45 pp. http://fsc.malham@ukonline.co.uk.

Godward, M., 1937. An ecological and taxonomic investigation of the littoral flora of Lake Windermere. Journal of Ecology 25: 496-568.

Gregory, W., 1857. On a post Tertiary lacustrine sand, containing diatomaceous exuviæ, from Glenshira, near Inverary. Transactions of the Edinburgh Botanical Society: 30-43 (Same article also included in 1857. Transactions of the Microscopical Society of London 5: 67-88).

Greiner, R., 2007. Phytate-degrading enzymes: regulation of synthesis in microorganisms and plants. In Turner, B. L., A. E. Richardson \& E. J. Mullaney (eds), Inositol Phosphates. Linking Agriculture and the Environment. CAB International, Wallingford, UK: 288 pp, pp. 78-96.

Gretz, M., 2008. The stalks of didymo. In Bothwell, M. L. \& S. A. Spaulding (eds), Proceedings of the 2007 International Workshop on Didymosphenia geminata. Canadian Technical Report on Fisheries and Aquatic Sciences 2795: 21.

Gretz, M. R., M. L. Riccio, T. R. Hungwe, H. M. Burger, S. N. Kiemle, M. D. Apoya \& S. A. Spaulding, 2006. Extracellular polymers of the stalked diatom Didymosphenia geminata. In Spaulding, S., R. Wiltshire \& L. Elwell (conference organizers), Current Knowledge of Didymosphenia geminata: Developing a Research and Management Response. Federation of Fly Fishers and EPA Region 8, held in association with Western Division American Fisheries Society Annual Meeting, May 15-16, 2006, Montana State University, Montana, USA: 29 pp, p. 13.

Hassall, A. H., 1845. A History of the British Freshwater Algae, Vol. I. Taylor, Walton \& Maberley, London: $462 \mathrm{pp}$.

Hedenstróm, A. \& J. Risberg, 1999. Early Holocene shoredisplacement in southern central Sweden as recorded in elevated isolated basins. Boreas 28: 490-504.

Héribaud, J., 1893. Les Diatomées d'Auvergne. Librairie de Sciences Naturelles Paul Klincksieck, Paris, France: 255 pp.

Hermann, A. K., K. A. Lane, D. P. Pite, S. A. Spaulding \& B. P. Finney, 2008. Abstract, 20th International Diatom Symposium, 7-13 September 2008, Dubrovnik, Croatia: $143 \mathrm{pp}$.

Heuff, H. \& K. Horkan, 1984. Caragh. In Whitton, B. A. (ed.), Ecology of European Rivers. Blackwell, Oxford: 644 pp, pp. 363-384.

Hirano, M, 1966. Freshwater algae of Karakoram and SwatHimalaya. Results of the Kyoto University Scientific Expedition to the Karakoram and Hindu Kush, 1955, Vol. VIII. Additional Reports, Kyoto University: 55-66.

Hoagland, K. D., S. C. Roemer \& J. R. Rosowski, 1982. Colonization and community structure of two periphyton assemblages, with emphasis on the diatoms (Bacillariophyceae). American Journal of Botany 69: 188-213.

Hoffmann, J. P., 1990. Dependence of photosynthesis and vitamin $\mathrm{B}_{12}$ uptake on cellular vitamin $\mathrm{B}_{12}$ concentration in the multicellular alga Cladophora glomerata (Chlorophyta). Limnology \& Oceanography 35: 100-108.

Holmes, N. T. H. \& B. A. Whitton, 1981. Phytobenthos of the River Tees and its tributaries. Freshwater Biology 11: 139-165.

Hustedt, F., 1938. Diatomeen aus den Pyrenäen. Berichte Deutsche Botanische Gesellschaft 56: 543-572 (in German).

Ireland, M. E., J. A. Kerby, E. M. Quardokus, J. P. Reilly \& Y. V. Brun, 2002. Proteomic analysis of the Caulobacter crescentus stalk indicates competence for nutrient uptake. Molecular Microbiology 45: 1029-1041.

Jellyman, P. G., S. J. Clearwater, B. J. F. Biggs, N. Blair, D. C. Bremner, J. S. Clayton, A. Davey, M. R. Gretz, C. Hickey \& C. Kilroy, 2006. Didymosphenia geminata experimental control trials (product screening and testing) and stalk degradation studies. National Institute of Water and Atmospheric Research, New Zealand, Client Report CHC2006-128, NIWA Project MAF6504.

Johansson, C., 1982. Attached algal vegetation in running waters of Jämtland, Sweden. Acta Phytogeographica Suecica 71: 1-84.

Jónsson, G. S., I. R. Jónsson, M. Björnsson \& S. M. Einarsson, 2000. Using regionalization in mapping the distribution of the diatom species Didymosphenia geminata (Lyngb.) M. Schmidt in Icelandic rivers. Verhandlung Internationale Vereinigung Limnologie 27: 340-343.

Jónsson, I. R., G. S. Jónsson \& S. M. Einarsson, 2006. Distribution of Didymosphenia geminata in Iceland. In Spaulding, S., R. Wiltshire, \& L. Elwell (conference organizers), Current Knowledge of Didymosphenia geminata: Developing a Research and Management Response. Federation of Fly Fishers and EPA Region 8, held in association with Western Division American Fisheries Society Annual Meeting, May 15-16, 2006, Montana State University, Montana, USA: 29 pp, p. 14.

Jónsson, I. R., G. S. Jónsson, J. S. Olafsson, S. M. Einarsson \& Th. Antonsson, 2008. Occurrence and colonization pattern of Didymosphenia geminata in Icelandic streams. In Bothwell, M. L. \& S. A. Spaulding (eds), Proceedings of the 2007 International Workshop on Didymosphenia geminata. Canadian Technical Report on Fisheries and Aquatic Sciences 2795: 41-44.

Kara, H. \& B. Şahin, 2001. Epipelic and epilithic algae of Değirmendere River (Trabzon, Turkey). Turkish Journal of Botany 25: 177-186.

Kawecka, B., 1965. Communities of benthic algae in the River Białka and its Tatra tributaries the Rybi Potok and Roztoka. Komitet Zagosp. Ziem. Górskich PAN 13: 113-129.

Kawecka, B., 1966. Glony osiadłe na Potamogeton sp. w Morskim Oku (Aufwuchsalgen auf Potamogeton sp. in See Morskie Oko. Acta Hydrobiologica 8: 321-328 (Polish, with German summary).

Kawecka, B., in press a. Diatom diversity in streams of the Tatra National Park (Poland) as indicators of environmental conditions. In Witkowski, A. (ed.), Diatom Monographs. A.R.G. Gantner Verlag K.G. 
Kawecka, B., in press b. Diatom diversity of the lower part of the Sljudjanka river draining the Chamar-Daban Mountains (Southern part of the Lake Baikal catchment, Siberia, Russia)—preliminary results. Oceanological and Hydrobiological Studies.

Kawecka, B. \& P. Eloranta, 1987. Communities of sessile algae in some small streams of central Finland. Comparison of the algae of the high mountains of Europe and those of its northern regions. Acta Hydrobiologica 29: 403-415.

Kawecka, B. \& M. Olech, 2004. Diatom diversity of streams in Finnish Lapland and maritime Antarctica. In Poulin, M. (ed.), 17th International Diatom Symposium 2002, Ottawa, Canada. Biopress Ltd., Bristol, UK: 161-186.

Kawecka, B. \& J. Sanecki, 2003. Didymosphenia geminata in running waters of southern Poland-symptoms of change in water quality? Hydrobiologia 495: 193-201.

Kawecka, B. \& B. Szczęsny, 1984. Dunajec. In Whitton, B. A. (ed.), Ecology of European Rivers. Blackwell, Oxford: 644 pp, pp. 499-525.

Kelly-Quinn, M., C. Bradley, I. Dodkins, T. J. Harrington, B. Ni Chathain, M. O'Connor, B. Rippey \& D. Trigg, 2006. Water Framework Directive-Characterization of Reference Conditions and Testing of Typology of Rivers (2002W-LS-7) Final Report. Environmental Protection Agency, PO Box 3000, Co. Wexford, Ireland: 56 pp.

Kienel, U. \& T. Kumke, 2002. Combining ordination techniques and geostatistics to determine the patterns of diatom distributions at Lake Lama, Central Siberia. Journal of Paleolimnology 28: 181-184.

Kilroy, C., 2004. A new alien diatom, Didymosphenia geminata (Lyngbye) Schmidt: its biology, distribution, effects and potential risks for New Zealand fresh waters. NIWA, Christchurch, New Zealand: 34 pp.

Kilroy, C., 2008. Didymosphenia geminata in New Zealand: distribution, dispersal and ecology of a non-indigenous invasive species. In Bothwell, M. L. \& S. A. Spaulding (eds), Proceedings of the 2007 International Workshop on Didymosphenia geminata. Canadian Technical Report on Fisheries and Aquatic Sciences 2795: 15-20.

Kilroy, C., B. J. Biggs \& C. C. Vieglais, 2007a. Didymosphenia geminata in New Zealand: a science response to help manage an unwanted, invasive freshwater diatom. Abstract, American Society for Limnology \& Oceanography, February 4-9, 2007.

Kilroy, C, A. Lagerstedt, A. Davey \& K. Robinson, 2007b, Studies on the survivability of the invasive diatom Didymosphenia geminata under a range of environmental and chemical conditions. NIWA Client Report CHC2006-116: $110 \mathrm{pp}$.

Kilroy, C., T. Snelder, O. Floerl, C. C. Vieglais \& K. Dey, 2008. A rapid technique for assessing the suitability of areas for invasive species applied to New Zealand's rivers. Diversity and Distributions 14: 262-272.

Kirkwood, A. E., T. Shea, L. J. Jackson \& E. McCauley, 2007. Didymosphenia geminata in two Alberta headwater rivers: an emerging invasive species that challenges conventional views on algal bloom development. Canadian Journal of Fisheries and Aquatic Sciences 64: 1703-1709.

Kirkwood, A. E., L. J. Jackson \& E. McCauley, 2008. Didymosphenia geminata distribution and bloom formation along the south-eastern slopes of the Canadian Rockies. In Bothwell, M. L. \& S. A. Spaulding (eds), Proceedings of the 2007 International Workshop on Didymosphenia geminata. Canadian Technical Report on Fisheries and Aquatic Sciences 2795: 22-24.

Klausmeier, C. A., E. Litchman, T. Daufresne \& S. A. Levin, 2004. Optimal nitrogen-to-phosphorus stoichiometry of phytoplankton. Nature 429: 171-174.

Kociolek, J. P. \& B. De Reviers, 1996. The diatom types of Emile Manguin. II. Validating descriptions and designation of types for the New Caledonia species. Cryptogamie Algologies 17: 193-215.

Kociolek, J. P. \& S. A. Spaulding, 2003. Symmetrical naviculoid diatoms. In Wehr, J. D. \& R. D. Sheath (eds), Freshwater Algae of North America. Ecology and Classification. Academic Press, Amsterdam etc.: 918 pp, pp. 637-668.

Kociolek, J. P. \& E. F. Stoermer, 1988. A preliminary investigation of the phylogenetic relations among the freshwater, apical pore field-bearing cymbelloid and gomphonemoid diatoms (Bacillariophyceae). Journal of Phycology 24: 277-385.

Kociolek, J. P., R. Flower \& G. Reid, 2000. Valve ultrastructure of Didymosphenia dentata (Bacillariophyta): an endemic diatom species from Lake Baikal. Nova Hedwigia 71: 113-120.

Koksvik, J. I. \& H. Reinertsen, 2008. Changes in macroalgae and bottom fauna in the winter period in the regulated Alta river in northern Norway. River Research and Applications 24: 720-731.

Kolayli, S. \& B. Şahin, 2007. A taxonomic study on the phytoplankton in the littoral zone of Karagöl Lake (BorçkaArtvin/Turkey). Turkish Journal of Fisheries and Aquatic Sciences 7: 171-175.

Kolayli, S., A. Baysal \& B. Şahin, 1998. A study of the epipelic and epilithic algae of Şana River (Trabzon, Turkey). Turkish Journal of Botany 22: 163-170.

Kolmakov, V. I., O. V. Anishchenko, E. A. Ivanova, M. I. Gladyshev \& N. N. Sushchik, 2008. Estimation of periphytic microalgae grow primary production with DCMUfluorescence method in Yenisei River (Siberia, Russia). Journal of Applied Phycology 20: 289-297.

Komulaynen, S., 2008. The structure and distribution of phytoperiphyton in the Teno River and its tributaries (Finnish Lapland). Boreal Environment Research 13: 517-524.

Kozhova, O. M. \& L. R. Izmestéva, 1998. Lake Baikal. Evolution and Biodiversity. Backhuys, The Netherlands: $447 \mathrm{pp}$.

Krammer, K. \& H. Lange-Bertalot, 1999. Bacillariophyceae. Naviculaceae. In Ettl, H., J. Gerloff, H. Heynig \& D. Mollenhauer (eds), Süsswasserflora von Mitteleuropa 2/1. Akademischer Verlag, G. Fischer, Heidelberg, Berlin: $876 \mathrm{pp}$.

Kravtsova, L. S., R. M. Kamaltynov, E. B. Karabanov, I. V. Mekhanikova, T. Ya, N. A. Sitnikova, Z. V. Rozhkova, L. A. Slugina, I. V. Izhboldina, T. V. Weinberg, D. Akinshina \& Yu. Sherbakov, 2004. Macrozoobenthic communities of underwater landscapes in the shallow-water zone of southern Lake Baikal. Hydrobiologia 522: 193-205.

Kravtsova, L. S., I. V. Weinberg, I. V. Khanaev, D. Yu Sherbakov, S. V. Semovsky, F. V. Adov, N. A. Rozhkova, 
G. V. Pomazkina, N. G. Shevelyova \& I. A. Kaygorodova, 2006. The formation of a fouling community on artificial substrate in Lake Baikal. Hydrobiologia 568: 51-55.

Kumar, S., S. A. Spaulding, T. J. Stohlgren, K. A. Hermann, T. S. Schmidt \& L. L. Bahls, 2009. Potential habitat distribution for the freshwater diatom Didymosphenia geminata in the continental US. Frontiers in Ecology and Environment: 7.

Lagerstedt, M. A., 2007. Didymosphenia geminata; an example of a biosecurity leak in New Zealand. Thesis in partial fulfilment of requirements for M.Sc. in Environmental Sciences, University of Canterbury, New Zealand: 94 pp.

Lamb, M. A. \& R. L. Lowe, 1987. Effects of current velocity on the physical structuring of diatom (Bacillariophyceae) communities. Ohio Journal of Science 87(3): 72-78.

Lange-Bertalot, H. \& S. I. Genkal, 1999. Diatoms from Siberia I, Inseln im Arktischen Ozean (Yugorsky-Shar Strait). In Lange-Bertalot, H. (ed.), Iconographia Diatomologica, Vol. 6. A.R.G. Gantner Verlag K.G., Liechtenstein: 5-269.

Lange-Bertalot, H. \& A. Steindorf, 1996. Rote List der limnischen Kieselalgen (Bacillariophyceae). Bundesamt für Naturschutz, Schriftenreihe für Vegetationskunde 28: 633-677.

Larned, S., B. Biggs, N. Blair, C. Burns, B. Jarvie, D. Jellyman, C. Kilroy, J. Leathwick, K. Lister, J. Nagels, M. Schallenberg, S. Sutherland. J. Sykes, W. Thompson, K. Vopel \& B. Wilcock, 2006. Ecology of Didymosphenia geminata in New Zealand. Habitat and ecosystem effects-Phase 2. National Institute of Water and Atmospheric Research Client Report CHC2006-086, NIWA Project MAF06507.

Larned, S., D. Arscott, N. Blair, B. Jarvie, D. Jellyman, K. Lister, M. Schallenberg, S. Sutherland, K. Vopel \& B. Wilcock, 2007. Ecological studies of Didymosphenia geminata in New Zealand, 2006-2007. NIWA Client Report CHC2007-070; NIWA Project MAF07507: 120 pp.

Larson, A. M., 2007. Relationships between nuisance blooms of Didymosphenia geminata and measures of aquatic community composition in Rapid Creek, South Dakota. Water Resources Assistance Program, Division of Financial and Technical Assistance, South Dakota Department of Environment and Natural Resources: vii +28 pp.

Larson, A. M. \& J. Carreiro, 2008. Relationship between nuisance blooms of Didymosphenia geminata and measures of aquatic community composition in Rapid Creek, South Dakota. In Bothwell, M. L. \& S. A. Spaulding (eds), Proceedings of the 2007 International Workshop on Didymosphenia geminata. Canadian Technical Report on Fisheries and Aquatic Sciences 2795: 45-49.

Lee, P., M. M. Ring, C. Brown, B. W. Taylor \& T. A. Weilnitz, 2008. How scour disturbance affects Didymosphenia geminata abundance and the associated epiphyte community. Poster 35-13. 93rd ESA Annaul Meeting, August 3-August 8, 2008, Milwaukee, Wisconsin, USA.

Li, Y., P. Xie, Z. Gong \& Z. Shi, 2003. Cymbellaceae and Gomphonemataceae (Bacillariophyta) from the Hengduan Mountains region (southwestern China). Nova Hedwigia 76(3-4): 507-536.

Li, Y., P. Xie, Z. Gong \& Z. Shi, 2004. A survey of the Gomphonemaceae and Cymbellaceae (Bacillariophyta) from the Jolmolungma Mountain (Everest) Region of China. Journal of Freshwater Ecology 19: 189-192.

Lindstrøm, E.-A. \& O. Skulberg, 2007. Didymosphenia geminata (Lyngbye) M. Schmidt, an indigenous constituent of the algal flora in Norwegian watercourses (Abstract ID 524). American Society for Limnology \& Oceanography, Santa Fe, February 4-9, 2007.

Lindstrøm, E.-A. \& O. Skulberg, 2008. Didymosphenia geminata-a native diatom species of Norwegian rivers coexisting with the Atlantic salmon. In Bothwell, M. L. \& S. A. Spaulding (eds), Proceedings of the 2007 International Workshop on Didymosphenia geminata. Canadian Technical Report on Fisheries and Aquatic Sciences 2795: 35-40.

Livingstone, D. \& B. A. Whitton, 1984. Water chemistry and phosphatase activity of the blue-green alga Rivularia in Upper Teesdale streams. Journal of Ecology 72: 405-421.

Lord, J. K., 1866. The Naturalist in Vancouver Island and British Columbia, Vols. I, 2. Richard Bentley, London: $733 \mathrm{pp}$.

Lowe, C. W., 1924. The freshwater algae of central Canada. Transactions of the Royal Society of Canada, Section V: 19-48.

Løvstad, O., 2008. A phosphorus-based biological classification system and threshold indicators. Verhandlung Internationale Vereinigung Limnologie 30: 565-568.

Lyngbye, H. C., 1819. Tentamen Hydrophytologiae Danicae Continens Omnia Hydrophyta, Cryptogamia Daniae. Holsatiae, Faeroae, Islandiae, Groenlandia, Lucusque, Cognita, Systematicae, Disposita, Descripta et Icaribus Illustrata. Adjedis Simul Speciebus Norwegicus, Hafniae, Leipzig.

MacClement, W. T., 1915. A preliminary report of the plants of the Georgian Bay. Contributions to Canadian Biology 1911-1914, Fasc.II: 201-211.

Manguin, E., 1960. Contribution à la flore diatomique de l'Alaska Lac Karluk, espèces critiques ou nouvelles. Revue Algologie 5: 266-288.

Manguin, E., 1962. Contribution à la connaissance de la flore diatomique de la Nouvelle-Caledonie. Mémoirs Muséum National Histoire Naturelle Nouveau Série B Botanique 12(1): 1-40.

Margalef, R., 1953. Materiales para la hidrobiología de la Isla de Mallorca. Publicado del Instituto Biologia Aplicata Barcelona 11: 5-111.

Mather, W. M., 1928. Freshwater algae of the Hutt Valley. MSc. Thesis, Victoria University, Wellington.

Maurer, K., 2008. Investigation of phosphorus uptake capability in, the diatom Didymosphenia geminata. Proceedings 2008 American Society for Engineering Education Conference: $6 \mathrm{pp}$.

McKelvie, I. D., 2007. Inositol phosphates in aquatic systems. In Turner, B. L., A. E. Richardson \& E. J. Mullaney (eds), Inositol Phosphates. Linking Agriculture and the Environment. CAB International, Wallingford, UK: 288 pp, pp. 261-277.

McNyset, K. M. \& M. L. Julius, 2006. Potential geographic distribution of Didymosphenia geminata (Lyngbye) M. Schmidt in North America based on ecological niche models. In Spaulding, S., R. Wiltshire \& L. Elwell (conference organizers), Current Knowledge of 
Didymosphenia geminata: Developing a Research and Management Response. Federation of Fly Fishers and EPA Region 8, held in association with Western Division American Fisheries Society Annual Meeting, May 15-16, 2006, Montana State University, Montana, USA: 29 pp, p. 18.

Medvedeva, L. A., 2001. Biodiversity of aquatic algal communities in the Sikhote-Alin biosphere reserve (Russia). Cryptogamie Algologie 22: 65-100.

Metzeltin, D. \& H. Lange-Bertalot, 1995. Kritische Wertung der Taxa in Didymosphenia (Bacillariophyceae). Nova Hedwigia 60: 381-405.

Metzeltin, D. \& A. Witkowski, 1996. Diatomeen der BärenInsel. In Lange-Bertalot, H. (ed.), Iconographia Diatomologica, Vol. 4. Koeltz Scientific Books, Germany: 3-287.

Meyer, K., 1929. Über die Auxensporenbildung bei Gomphonema geminatum. Archiv für Protistenkunde 66: 421-435.

Mississippi Interstate Cooperative Resource Association, 2008. New didymo control to be tested. River Crossings 15(5): 2.

Moffat, M. C., 1994. An ultrastructural study of Didymosphenia geminata (Bacillariophyceae). Transactions of the American Microscopical Society 113: 59-71.

Moore, J. W., 1979. Seasonal changes in the standing crop of an epilithic algal population on the north shore of Great Slave Lake. Canadian Journal of Botany 57: 17-22.

Moore, L. F. \& D. A. McLarty, 1975. The influence of soil water extract and thiamine on the growth of Cladophora glomerata. Canadian Journal of Botany 53: 530-535.

Moore, J. W., M. J. Hardin \& G. A. Sergy., 1978. The effects of metal mines on aquatic ecosystems in the Northwest Territories. I. Canadian Tungsten Mining Corporation. Canadian Environmental Protection Service Surveillance Report EPS-NW-78-8.

Mrozińska, T., J. Czerwik-Marcinkowska \& M. Gradziński, 2006a. A new species of Didymosphenia (Bacillariophyceae) from the Western Carpathian Mountains of Poland and Slovakia. Nova Hedwigia 83: 499-510.

Mrozińska, T., J. Czerwik-Marcinkowska \& M. Gradziński, 2006b. Didymosphenia tatrensis Mroz., Czerw. et Gradz., a new species of the genus Didymosphenia found with D. geminata (Lyngb.) M. Sch. in the calcareous part of the Tara Mts (Western Carpathians, Poland and Slovakia). In Spaulding, S., R. Wiltshire \& L. Elwell (conference organizers), Current Knowledge of Didymosphenia geminata: Developing a Research and Management Response. Federation of Fly Fishers and EPA Region 8, held in association with Western Division American Fisheries Society Annual Meeting, May 15-16, 2006, Montana State University, Montana, USA, 29 pp, p. 12.

Mrozińska-Broda, T. \& J. Czerwik-Marcinkowska, 2004. Eucaryotic algae and cyanobacteria in the River Dunajec upstream and downstream from the new dam reservoirs in Czorsztyn and Sromowce and their use for monitoring. Oceanological and Hydrobiological Studies 33(3): 83-97.

Müller, O. F., 1786. Animalicula Infusoria, Fluviatia et Marina. Hafniae, Leipzig: $531 \mathrm{pp}$.

Mundie, J. H. \& D. G. Crabtree, 1997. Effects on sediments and biota and cleaning a salmonid spawning channel. Fisheries Management and Ecology 4: 111-126.
Nelson, R. R., T. O. Odlaug, B. O. Krogstad, O. R. Ruschmeyer \& T. A. Olson, 1973. The effects of enrichment on Lake Superior periphyton. Water Resources Research Center Bulletin 59, Minneapolis, USA: $182 \mathrm{pp}$.

New Zealand Parliamentary Library, 2006. Didymosphenia geminata (Didymo) in New Zealand. Parliamentary Library Research Papers, 15 December 2006, 4 pp.

Nikulina, T. V., V. V. Bogatov \& M. V. Astakhov, 2008. Colonization of artificial substrates of periphyton algae in Kedrovaya River (Primorye Territory). Vladimir Ya. Levanidov's Biennial Memorial Meetings 4: 46-55 (in Russian).

Noga, T., 2003. Dispersion of Didymosphenia geminata in the flowing waters of southern Poland-new sites of species occurrence in the Orawska watershed and the Orawska basin. Oceanological and Hydrobiological Studies 32(4): 159-170.

Northcote, T. G., Ennis, G. L. \& M. H. Anderson, 1975. Periphytic and planktonic algae of the lower Fraser River in relation to water quality conditions. Westwater Technical Reports 8: 1-59 (Westwater Research Center, University of Brritish Columbia, Vancouver).

Novikmec, M., M. Svitok, E. Bulánková, Z. ČiamporováZaťovičová, T. Derka, J. Halgoš, L. Hamerlík, D. Illéšová, M. Illyová, I. Krno, J. Lukáš, D. Némethová, Z. Pastuchová, S. Stašiov, F, Šporka, E. Štefková, E. Tirjaková, J. Tomajka \& P. Bitušík, 2007. Limnology of Streams in the Poloniny National Park (the East Carpathians, Slovakia). Technical University in Zvolen, Slovakia: 69 pp.

Okuno, H., 1944. Studies on Japanese diatomite deposits. II. Botanical Magazine of Tokyo 58: 8-14.

Pentecost, A., 2005. Travertine. Springer, The Netherlands: 446.

Pepin, D. M. \& F. R. Hauer, 2002. Benthic responses to groundwater-surface water exchange in 2 alluvial rivers in northwestern Montana. Journal of the North American Benthological Society 21: 370-383.

Pomazkina, G. V., Ye. V. Rodionova \& O. M. Mushnikova, 2008. Microphytobenthos in southern Baikal (Russia). Algologia 18(2): 160-172.

Prescott, G. W. \& G. E. Dillard, 1979. A Checklist of Algal Species Reported from Montana 1891-1977. Monograph No. 1, Montana Academy of Sciences, Supplement to the Proceedings, Vol. 38: 102 pp.

Quiquampoix, H. \& D. Mousain, 2005. Enzymatic hydrolysis of organic phosphorus. In Turner, B. L., E. Frossard \& D. S. Baldwin (eds), Organic Phosphorus in the Environment. CAB International, Wallingford, UK: 89-112.

Ramírez, P. R., 2006. Estado de conocimiento de las diatoméas dulceacuícolas de Chile. The state of knowledge of freshwater diatoms of Chile. Gayana Botanica 70: 1-7.

Razjigaeva, N. G., A. M. Korotky, T. A. Grebennikova, L. A. Ganzey, L. M. Mokhova, V. B. Bazarova, L. D. Sulerzhitsky \& K. A. Lutaenko, 2002. Holocene climatic changes and environmental history of Iturup Island, Kurile Islands, northwestern Pacific. The Holocene 12: 469-480.

Redfield, A. C., B. H. Ketchum \& F. A. Richards, 1963. The influence of organisms on the composition of sea water. In Hill, M. H. (ed.), The Sea, Vol. 2. Wiley-Interscience, Hoboken, NJ: 26-77. 
Rivera, P., 1983. A guide for references and distribution for the class Bacillariophyceae in Chile between $18^{\circ} 28^{\prime} \mathrm{S}$ and $58^{\circ} \mathrm{S}$. Bibliotheca Diatomologica 1-386.

Robinson, C. T. \& B. Kawecka B., 2005. Benthic diatoms of an Alpine stream/lake network in Switzerland. Aquatic Sciences 67: 492-506 (With erratum in 2007, Aquatic Sciences 69: 584-589).

Rost, A. L., C. H. Fritsen, J. Memmott, C. Davis \& E. Withlin, 2008. Environmental controls and potential food web impacts of Didymosphenia geminata, a comparative ecosystem study. In Bothwell, M. L. \& S. A. Spaulding (eds), Proceedings of the 2007 International Workshop on Didymosphenia geminata. Canadian Technical Report on Fisheries and Aquatic Sciences 2795: 25.

Round, F. E., 1993. A Review and Methods for the Use of Epilithic Diatoms for Detecting and Monitoring Changes in River Water Quality 1993. Methods for the Examination of Waters and Associated Materials. HMSO, London: $65 \mathrm{pp}$.

Round, F. E., 1984. The Ecology of Algae. Cambridge University Press, Cambridge: vii +653 pp.

Round, F. E., R. M. Crawford \& D. G. Mann, 1990. The Diatoms. Biology \& Morphology of the Genera. Cambridge University Press, Cambridge: 747 pp.

Şahin, B., 2000. Algal flora of Lakes Aygir and Balikli (Trabzon, Turkey). Turkish Journal of Botany 24: 35-45.

Şahin, B., 2001. Epipelic and epilithic algae of Dağbasi Lake (Rize-TURKEY). Turkish Journal of Botany 25: 187-194.

Şahin, B., 2003. Epipelic and epilithic algae of lower parts of Yanbolu River (Trabzon, Turkey). Turkish Journal of Botany 27: 107-115.

Schmidt, J. M. \& R. Y. Stanier, 1966. The development of cellular stalks in bacteria. Journal of Cell Biology 28: 5011-5026.

Schmidt-Nielsen, S. \& H. Printz, 1915. Drammenselvens forurensning ved træmasse, cellulose- og papirfabrikkenen 1911 og 1912. Biologiske og kjemiske undersøgelser, A. W. Brøggers boktrykkeri Kristiania: 142 pp (cited by Lindstrøm \& Skulberg, 2008).

Shearer, J. \& J. Erickson, 2006. Didymosphenia geminata and the Rapid Creek brown trout fishery, South Dakota. In Spaulding, S., R. Wiltshire \& L. Elwell (conference organizers), Current Knowledge of Didymosphenia geminata: Developing a Research and Management Response. Federation of Fly Fishers and EPA Region 8, held in association with Western Division American Fisheries Society Annual Meeting, May 15-16, 2006, Montana State University, Montana, USA: 29 pp, p. 22.

Sheath, R. G. \& A. D. Steinman, 1982. A checklist of freshwater algae of the Northwest Territories, Canada. Canadian Journal of Botany 60: 1964-1997.

Sherbot, D. J. M. \& M. L. Bothwell, 1993. Didymosphenia geminata (Gomphonemaceae). A review of the ecology of D. geminata and the physicochemical characteristics of endemic catchments on Vancouver Island. National Hydrology Research Institute, Environment Canada, Saskatoon, Sask. NHRI Contribution 93005: 66 pp.

Siemińska, J., 1964. Chrysophyta 2. BacillariophyceaeOkrzemki. In Starmach, K. (ed.), Flora Słodkowodna Polski, Vol. 6. PWN, Warszawa: 609 pp.
Simard, I. \& M. Simoneau, 2008. Didymo dans les rivières du Québec: état de situation. In Bothwell, M. L. \& S. A. Spaulding (eds), Proceedings of the 2007 International Workshop on Didymosphenia geminata. Canadian Technical Report on Fisheries and Aquatic Sciences 2795: 3-5 (French, with English abstract).

Sims, P. 2007. The diatoms (Bacillariophyta). In Guiry, M. D., D. M. John, F. Rindi \& T. K. McCarthy (eds), New Survey of Clare Island, Vol. 6: The Freshwater and Terrestrial Algae. Royal Irish Academy, Dublin: 254 pp, pp 115-139.

Skabichevsky, A. P., 1983. A new species of Didymosphenia lineata (Bacillariophyta) and its variability. Botanicheskii Zhurnal (Moscow \& Leningrad) 68: 1254-1260 (in Russian).

Skulberg, O. \& A. Lillehammer, 1984. Glåma. In Whitton, B. A. (ed.), Ecology of European Rivers. Blackwell, Oxford: 644 pp, pp. 469-498.

Skvortzow, B. V., 1935. Diatomes récoltées par le Père Licent au cours de ses voyages dans le nord de la Chine au bas Tibet, en Mongolie et en Mandjourie. Publications du Musée Hoangho Paiho de Tien Tsin. Tientsin 36: 1-43.

Skvortzow, B. V. \& E. I. Meyer, 1928. A contribution to the diatoms of Baikal Lake. Proceedings of the Sungaree River Biological Station 1: 1-55.

Smith, W., 1853. A Synopsis of the British Diatomaceae, Vol. I. Smith \& Beck, London and Leipzig.

Smythe, L. A., 1973. Primary productivity in the Speed River. M.Sc. Thesis, University of Waterloo, Canada, $142 \mathrm{pp}$.

Spaulding, S. \& L. Elwell, 2007. Increase in nuisance blooms and geographic expansion of the freshwater diatom Didymosphenia geminata. Recommendations for response. United States Geological Survey White Paper web publication, January 2007: 33 pp.

Spaulding, S. A., K. A. Hermann \& T. Johnson, 2008. Confirmed distribution of Didymosophenia geminata (Lyngbe) Schmidt in North America. In Bothwell, M. L. \& S. A. Spaulding (eds), Proceedings of the 2007 International Workshop on Didymosphenia geminata. Canadian Technical Report on Fisheries and Aquatic Sciences 2795: 26-29.

Spaulding, S. A., M. R. Gretz, D. Beeson, \& K. Hermann, 2005. Expansion in ecological and geographical range of Didymosphenia geminata. 18th American Diatomist Symposium, Mobile, Alabama, Abstract book. 69 pp.

Stein, J. R., 1975. Freshwater algae of British Columbia. Syesis 8: 119-184.

Stein, J. R. \& C. A. Borden, 1979. Checklist of Freshwater Algae of British Columbia. Canadian Contribution to the UNESCO Program on Man and the Biosphere (MAB). Syesis 12: 3-39.

Stoermer, E. F., 1980. Characteristics of benthic algal communities in the upper Great Lakes. U.S. Environmental Protection Agency, Office of research and Development. Ecological Research Series EPA 600/3-80-073. Environmental Research Laboratory, Duluth, MN: 72 pp.

Stoermer, E. F., Q. Yu-Zao \& T. B. Ladewski, 1986. A quantitative investigation of shape variation in Didymosphenia (Lyngbye) M. Schmidt (Bacillariophyta). Phycologia 25: 494-502. 
Subakov-Simić, G. \& M. Cvijan, 2004. Didymosphenia geminata from the Tisza River (Serbia)-its distribution and specific morphological and ecological characteristics. Algological Studies 114: 53-66.

Subakov-Simić, G., M. Cvijan \& S. Čado, 2006. The range spreading of Didymosphenia geminata (Lyngb.) M. Schmidt in the waters of Serbia (Serbia and Montenegro, Europe). In Spaulding, S., R. Wiltshire \& L. Elwell (conference organizers), Current Knowledge of Didymosphenia geminata: Developing a Research and Management Response. Federation of Fly Fishers and EPA Region 8, held in association with Western Division American Fisheries Society Annual Meeting, May 15-16, 2006, Montana State University, Montana, USA: 29 pp, p. 24.

Swift, I. G., 1980. Vitamins and phytoplankton growth. In Morris, I. (ed.), The Physiological Ecology of Phytoplankton. Blackwell, Oxford: 329-368.

Szabó, E. K., 2004. Comparative analysis of the benthic diatoms of some Hungarian waters. Ph.D. Thesis, Szent István University, Hungary.

Szabó, E. K., K. T. Kiss, G. Taba \& É. Ács, 2005. Epiphytic diatoms of the Tisza River, Kisköre Reservoir and some oxbows of the Tisza River after the cyanide and heavy metal pollution in 2000. Acta Botanica Croatia 64: 1-46.

Tarasova, E. N. \& A. I. Mescheryakova, 1992. Modern state of the hydrochemical regime of Lake Baikal (Series editor: Galaxy, G. I.). Novosibirsk, Nauta: 141 pp (in Russian).

Tiji, A. \& S. Nergui, 2008. Didymosphenia geminata (Lyngb.). Mart. Schmidt. Diatom 24: 80-85.

Tuji, A., 2004. The diatom type materials of Haruo Okuno 1. Five diatom species described by Okuno (1943, 1944) from the Yatuka deposit. Bulletin of the National Science Museum, Tokyo, Series B 30(3): 79-88.

Turner, B. L., R. Baxter, N. T. W. Ellwood \& B. A. Whitton, 2001. Characterization of the phosphatase activities of mosses in relation to their environment. Plant Cell and Environment 24: 1165-1176.

Turner, B. L., R. Baxter, N. T. W. Ellwood \& B. A. Whitton, 2003. Seasonal phosphatase activities of mosses from Upper Teesdale, northern England. Journal of Bryology 25: 203-214.

Van de Vijver, B., M. Kelly, S. Blanco, A. Jarlman \& L. Ector, 2008. The unmasking of a subantarctic endemic: Psammothidium abundans (Manguin) Bukhtiyarova et Round in European rivers. Diatom Research 23: 233-242.

Vieglais, C. M., 2008. Management approaches to didymo: The New Zealand experience. In Bothwell, M. L. \& S. A. Spaulding (eds), Proceedings of the 2007 International Workshop on Didymosphenia geminata. Canadian Technical Report on Fisheries and Aquatic Sciences 2795: 54-55.

Vietti, K., A. Greene, D. McKnight \& M. Miller, 2007. Effect of summer storms on Didymosphenia growth and streambed coverage in sub-Alpine streams in Colorado. Abstract, American Society for Limnology \& Oceanography, February 4-9, 2007.

Votintsev, K. K., 1961. Hydrochemistry of Lake Baikal. Academy of Science, Publishing House of SSSR, Moscow: 311 pp (in Russian).
Votintsev, K. K., I. V. Glazunov \& A. P. Tolmacheva, 1965. Hydrochemistry of Rivers of Lake Baikal Drainage. Nauka, Moscow: 495 pp (in Russian).

Wang, Y., Y. Chen, C. Lavin \& M. R. Gretz, 2000. Extracellular matrix assembly in diatoms (Bacillariophyceae). IV. Ultrastructure of Achnanthes longipes and Cymbella cistula as revealed by high-pressure freezing/freeze substitution and cryo-field emission scanning electron microscopy. Journal of Phycology 36: 367-378.

Watts, H., 1886. Pond life about Oakleigh. Victoria Naturalist 3: 80 .

Weilhofer, C. L., S. Spaulding \& Y. Pan, 2006 Habitat characterization of Didymosphenia geminata in the western US. In Spaulding, S., R. Wiltshire \& L. Elwell (conference organizers), Current Knowledge of Didymosphenia geminata: Developing a Research and Management Response. Federation of Fly Fishers and EPA Region 8, held in association with Western Division American Fisheries Society Annual Meeting, May 15-16, 2006, Montana State University, Montana, USA: 29 pp, p. 26.

Wetzel, R. G., 1992. Gradient-dominated ecosystems: Sources and regulatory functions of dissolved organic matter in freshwater ecosystems. Hydrobiologia 229: 181-198.

Whitford, L. A., 1960. The current effect and growth of freshwater algae. Transactions of the American Microscopical Society 79: 302-309.

Whitton, B. A., 1988. Hairs in eukaryotic algae. In Round, F. E. (ed.), Algae and the Aquatic Environment. Contributions in Honour of J. W. G. Lund. Biopress, Bristol: 460 pp, pp. 446-460.

Whitton, B. A., 2002. Phylum Cyanophyta (Cyanobacteria). In John, D. M., B. A. Whitton \& A. J. Brook (eds), The Freshwater Algal Flora of the British Isles. Cambridge University Press, Cambridge: 702 pp, pp. 25-122.

Whitton, B. A. \& D. T. Crisp, 1984. Tees. In Whitton, B. A. (ed.), Ecology of European Rivers. Blackwell, Oxford: 644 pp, pp. 145-178.

Whitton, B. A. \& N. T. W. Ellwood, 2008. Growth and nutrient ecology of Didymosphenia in British Isles and other European countries. In Bothwell, M. L. \& S. A. Spaulding (eds), Proceedings of the 2007 International Workshop on Didymosphenia geminata. Canadian Technical Report on Fisheries and Aquatic Sciences 2795: 10-14.

Whitton, B. A., S. L. J. Grainger, G. R. W. Hawley \& J. W. Simon, 1991. Cell-bound and extracellular phosphatase activities of cyanobacterial isolates. Microbial Ecology 21: 85-98.

Whitton, B. A., P. N. G. Boulton, E. Clegg, J. J. Gemmell, G. G. Graham, R. Gustar \& T. P. Moorhouse, 1998a. Long-term changes in macrophytes of British rivers, Vol. 1. River Wear. Science of the Total Environment 210/211: 411-426.

Whitton, B. A., J. M. Yelloly, M. Christmas \& I. Hernández, 1998b. Surface phosphatase activity of benthic algal communities in a stream with highly variable ambient phosphate concentrations. Verhandlungen Internationale Vereinigung Limnologie 26: 967-972.

Whitton, B. A., A. M. Al-Shehri, N. T. W. Ellwood \& B. L. Turner, 2005. Ecological aspects of phosphatase activity in cyanobacteria, eukaryotic algae and bryophytes. In Turner, B. L., E. Frossard \& D. S. Baldwin (eds), Organic 
Phosphorus in the Environment. CAB International, Wallingford, UK: 205-241.

Whoriskey, F., 2008. Of didymo, Atlantic salmon and the management of fear. In Bothwell, M. L. \& S. A. Spaulding (eds), Proceedings of the 2007 International Workshop on Didymosphenia geminata. Canadian Technical Report on Fisheries and Aquatic Sciences 2795: xi-xii.

WIOŚ-Jaslo, 1996. Raport o stanie Środowiska w Województwie Podkarpackim (In Polish: The State of the Environment: Report on Subcarpathian Voivodeship).

WIOŚ-Kraków, 2000. Raport o stanie Środowiska w Województwie Krakowskim (In Polish: The State of the Environment: Report on Kraków Voivodeship).

Wyatt, K. H., F. R. Hauer \& G. F. Pessoney, 2008. Benthic algal response to hyporheic-surface water exchange in an alluvial river. Hydrobiologia 607: 151-161.

Zingmark, R. G., 1969. The Diatoms of Flathead Lake, Montana and Vicinity. M.A. Thesis, Humbolt State University, Arcata, California: $65 \mathrm{pp}$.

\section{Author Biographies}

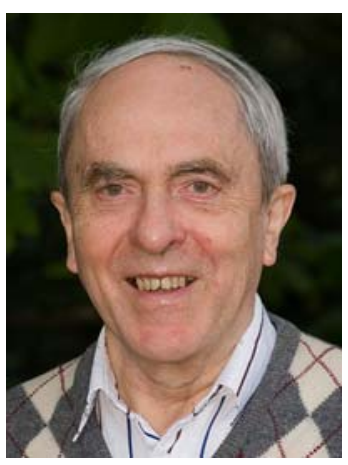

B. A. Whitton is emeritus professor at the University of Durham, England. His early interests were mainly on the physiological ecology of algae and bryophytes in metal-rich and highly acidic streams, but later included blue-green algae of Aldabra Atoll and deepwater ricefields of Bangladesh. For the past twenty years he has returned to the questions raised during his $\mathrm{PhD}$ research relating to acquisition of phosphorus when the element is in short supply. Increasingly this has concerned the importance of organic phosphate in many environments. In addition to trying to answer questions about algae, he maintains a national collection of the flowering plant Corydalis in his garden and has written books and articles on the artist John Tunnard-a near surrealist who sometimes showed algae in his paintings.

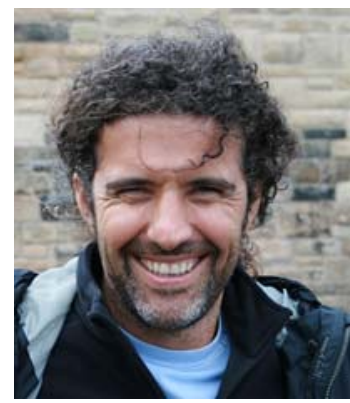

N. T. W. Ellwood graduated from the University of Newcastle-upon-Tyne (PhD, 2002) on a project carried out in collaboration with the University of Durham (UK). $\mathrm{He}$ is presently a postdoc at the University of Rome (Roma Tre) working in conjunction with the University of 'Tor Vergata' (Italy) on phytoplankton dynamics and water chemistry of volcanic

lakes in the Lazio region. His main research interests include biological monitoring of flowing and standing freshwaters, nutrient dynamics of freshwaters, nutrient uptake of planktonic and benthic algae, and surface enzyme activities and community structures.

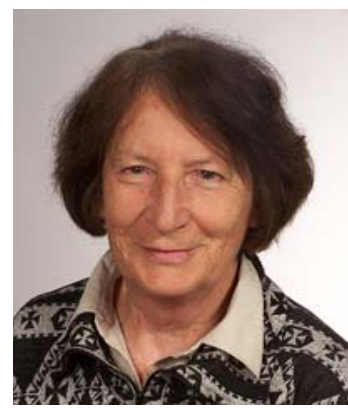

B. Kawecka is emeritus professor at the Institute of Nature Conservation PAS in Kraków, Poland. Her main research interest has been on the taxonomy and ecology of diatoms in high mountain streams. This started and continued with studies in the Polish Tatra Mountains, but subsequently there have been opportunties to compare these diatom communities with those of other high mountains in Europe and also streams in Finnish Lapland and, most recently, with those of mountains in the catchment of Lake Baikal. The mountain studies include collaboration with EAWAG (Switzerland) on long-term monitoring of diatoms in alpine streams. A 20-year study on diatom communities from streams in the Antarctica (mainly King George Island) is now part of the international project "Aliens in Antarctica". 